\title{
RESEARCH
}

Open Access

\section{Rural households' livelihood vulnerability to climate variability and extremes: a livelihood zone-based approach in the Northeastern Highlands of Ethiopia}

\author{
Abebe Arega Mekonen ${ }^{1,2^{*}}$ (D) and Arega Bazezew Berlie ${ }^{2}$
}

\begin{abstract}
Background: The adverse effects of climate variability and extremes exert increasing pressure on rural farm households whose livelihoods are dependent on nature. However, integrated and area-specific vulnerability assessments in Ethiopia in general and the study area, in particular, are scarce and insufficient for policy implications. Therefore, this study aims to quantify, map, classify, and prioritize the level of vulnerability in terms of the components of exposure, sensitivity, and adaptive capacity in the Northeastern Highlands of Ethiopia. The study area is divided into six livelihood zones, namely, Abay-Beshilo Basin (ABB), South Wollo and Oromia eastern lowland sorghum and cattle (SWS), Chefa Valley (CHV), Meher-Belg, Belg, and Meher. A total of 361 sample households were selected using proportional probability sampling techniques. Survey questionnaire, key informant interview, and focus group discussions were used to collect the necessary data. Rainfall and temperature data were also used. Following the IPCC's climate change vulnerability assessment approach, the climate vulnerability index (CVI) framework of Sullivan and Meigh's model was used to assess the relative vulnerability of livelihoods of rural households. Twenty-four vulnerability indicators were identified for exposure, sensitivity, and adaptive capacity components. In this regard, lyengar and Sudarshan's unequal weighting system was applied to assign a weight to indicators.

Results: The results revealed that Belg and Meher were found to be the highest exposure livelihood zones to vulnerability with an aggregated value of 0.71 . Equally, SWS, ABB, Belg, and CHV livelihood zones showed moderate level of sensitivity to vulnerability with an aggregated value between 0.45 and 0.60 . The study noted that livelihood zone of Belg (0.75) was found to be at high level of livelihood vulnerability. ABB (0.57) and CHV (0.45) were at a moderate level of livelihood vulnerability while Meher-Belg (0.22) was the least vulnerable livelihood zone due to a high level of adaptive capacity such as infrastructure, asset accumulation, and social networks.
\end{abstract}

\footnotetext{
* Correspondence: abebemekkon@gmail.com

'Department of Geography and Environmental Studies, Bahir Dar University, P.O. Box 79, Bahir Dar, Ethiopia

${ }^{2}$ Department of Geography and Environmental Studies, Debremarkos

University, P.O. Box 269, Debremarkos, Ethiopia
}

\section{Springer Open}

(c) The Author(s). 2021 Open Access This article is licensed under a Creative Commons Attribution 4.0 International License, which permits use, sharing, adaptation, distribution and reproduction in any medium or format, as long as you give appropriate credit to the original author(s) and the source, provide a link to the Creative Commons licence, and indicate if changes were made. The images or other third party material in this article are included in the article's Creative Commons licence, unless indicated otherwise in a credit line to the material. If material is not included in the article's Creative Commons licence and your intended use is not permitted by statutory regulation or exceeds the permitted use, you will need to obtain permission directly from the copyright holder. To view a copy of this licence, visit http://creativecommons.org/licenses/by/4.0/. 
Conclusion: It was identified that disparities of livelihood vulnerability levels of rural households were detected across the study livelihood zones due to differences in the interaction of exposure, sensitivity, and adaptive capacity components. The highest levels of exposure and sensitivity combined with low level of adaptive capacity have increased households' livelihood vulnerability. More importantly, the biophysical and socioeconomic sensitivity to livelihood vulnerability were exacerbated by slope/topography, soil erodibility, and population pressure. Therefore, designing livelihood zone-based identifiable adaptation strategies are essential to reduce the exposure and sensitivity of crop-livestock mixed agricultural systems to climate calamity.

Keywords: Exposure, Sensitivity, Adaptive capacity, Vulnerability Index, Sullivan and Meigh's model, Ethiopia

\section{Background}

In the twenty-first century, climate change has been identified as the greatest environmental challenge, and it will continue in the future across the world (Edame et al. 2011; Yohannes 2012; IPCC 2014). The global impact of climate change on both developed and developing countries is becoming a challenge for survival and livelihoods (Tesso et al. 2012). These changes are manifested through increasingly erratic rainfall, rising temperature, and severe floods and frequent droughts (Morand et al. 2012; Samson et al. 2011; Schlenker and Lobell 2010; Muller et al. 2011). The global average temperature has shown a warming trend of $0.85^{\circ} \mathrm{C}$ over the period 1880-2012 (IPCC 2014). The historical climate record for Africa, for example, exhibits $0.7{ }^{\circ} \mathrm{C}$ warming during the twentieth century (Hulme et al. 2001; IPCC 2001). Africa is one of the most vulnerable continents to climate variability and an extreme since its economy is largely dependent on climate-sensitive agriculture and weak adaptive strategies (IPCC 2007; Challinor et al. 2007; Gizachew and Shimelis 2014). Though agriculture plays a great role in the livelihood of rural communities in many African countries, it is highly vulnerable to climate change and extremes (Samson et al. 2011; Morand et al. 2012; Muller et al. 2011). These problems are compounded because Africa is characterized by nature-dependent livelihoods, indicating that the continent is excessively hit by adverse effects of climate variability and extremes (AfDB 2003; Daze et al. 2009; Gebreegziabher et al. 2018).

The impact of climate variability and extreme events on livelihood vulnerability are not the only variable by themselves rather influenced by a range of biophysical and socioeconomic factors (Feyissa et al. 2018; Deressa 2010). This implies that a system is vulnerable if it is exposed and sensitive to the effects of climate variability and extreme events, and simultaneously with limited adaptive capacity (Fellmann 2012). The low adaptive capacity due to limited choices or lack of access to resources increases communities' livelihood vulnerability to climate variability and extremes (ERI 2006; Herrmann et al. 2005). The manifestation and impact of vulnerability components (exposure, sensitivity and adaptive capacity) vary locally, so do the preferences and strategies (Piya et al. 2012). Investigation of vulnerability can be studied at the local scale since most of the vulnerability components (exposure, sensitivity, and adaptive capacity) are local events to a specific society and physical setting (Doll 2009; Feyissa et al. 2018).

The largest dependency on rainfed agriculture and threats that linked with climate variability and extremes resulted in households' livelihood vulnerability in Ethiopia (World Bank 2010; Deressa 2007). The increasing incidence of drought frequency coupled with other environmental challenges such as land degradation, deforestation, and loss of biodiversity has influenced the livelihoods of rural households (Mekonnen et al. 2019). The nature of landscape/topography that causes severe land degradation problems combined with the low level of households' adaptive capacity worsen the effects of climate variability and extremes (Simane et al. 2014; Deressa 2007). The largest dependence on the climatesensitive sector, unsound land use practice and management, and lack of required capital in adaptation option practices worsen the livelihood vulnerability of rural households to climate variability and extremes (Asrat and Simane 2017; Patt et al. 2009). Even in the future, the country will encounter a significant livelihoods' vulnerability to climate variability and extremes for 2050 scenario with the invariable sign of present adaptive capacity (Yohe et al. 2006). Further, Gebreegziabher et al. (2018) and Amare and Simane (2017) added that the inadequate economic resources, low educational level, and limited technology and infrastructure also suppress households' level of adaptive capacity and worsen their vulnerability to climate variability and extremes. More specifically, it can be said that the vulnerability of agricultural livelihoods in Ethiopia can be understood not only in terms of climate variability and extremes, but also determined by the socioeconomic and biophysical settings of the country. For instance, Gautam (2006), Dyoulgerov et al. (2011), and Daley (2015) indicate that the combined effect of population growth, limited availability of agricultural land, land over exploitation, cultivation of marginal lands, and lack of appropriate soil conservation practices led to water stress, drought, and 
crop failure exacerbates the vulnerability of rural household livelihoods in the country. The World Bank (2004) on the other hand noted that the steep slope and divided lands, too little and severely degraded lands, and erratic and inadequate rainfall are central to the vulnerability of agricultural livelihoods in the study area, in particular, and the northeastern highlands in general. The largest reliance on agriculture-based income, which is under the sensitivity of nature (unreliable and erratic rainfall), exposed the people to chronic food insecurity and poverty (Little et al. 2006; Kahsay 2013). Besides, the small per capita land possession as well as misuse and mismanagement of land resulted in high soil erosion and low soil fertility contributed to households' livelihood vulnerability across the study area livelihood zones (SWAD 2018; Kahsay 2013; Little et al. 2006; Negatu 2004).

Studies of vulnerability in Ethiopia (Abtew et al. 2009; Bewket 2009; Aberra 2011; Arega 2013; Mahoo et al. 2013; Gebreegziabher et al. 2018) were basically highlighting the impacts of climate change and variability on agricultural productivity and water sectors. These studies present useful understandings in the area of vulnerability to climate change and variability, and reflect the relationship between climate variability and vulnerability. Their scale of study is also either regional or local level based on agroecological zone. Rather households' vulnerability assessment of this study is based on livelihood zones that households share similar livelihood patterns (access to the same set of food and cash income sources, and similar market opportunities). Moreover, there is no earlier study available that integrates the approach of the IPCC (exposure, sensitivity, and adaptive capacity) with Climate Vulnerability Index (CVI) models for vulnerability assessment in the study area.

Therefore, the specific objectives of the study include to (i) analyze the interaction of geographic, biophysical, and socioeconomic components in terms of exposure, sensitivity, and adaptive capacity at the livelihood zone level, (ii) quantify and map the relative spatial variation of agricultural livelihood vulnerable hotspot areas at livelihood zone level using vulnerability index, and (iii) show site-specific priority areas (livelihood zones) for managing vulnerability using adaptive capacity enhancement.

\section{Theoretical framework of livelihood vulnerability assessment}

Vulnerability in scientific use has its roots in geographic and natural hazard researches. Nevertheless, vulnerability is now conceptualized differently by scholars from different areas of knowledge (Füssel 2007). Based on the aims to be achieved and the methods used, studies have been conceptualizing vulnerability differently (Downing et al. 2005; Gallopín 2006; ERI 2006; Deressa et al. 2008; Deressa 2010). The literature on the conceptual and methodological approaches to vulnerability analysis is summarized by Adger (1999), Füssel and Klein (2006), and Füssel (2007). The principal conceptual approaches in the analysis of vulnerability to climate variability and extreme events are the socioeconomic, biophysical, and integrated assessments.

The socioeconomic vulnerability assessment approach principally emphasizes on identifying the socioeconomic and political status of households (Adger 1999). Individual variation in education, gender, wealth, health status, access to credit, information and technology, formal and informal social capital, political power, and so on in a community are responsible for the variations in vulnerability levels (Deressa 2010; Deressa et al. 2008; Allen 2003). A study by Kelly and Adger (2000) is also an example of this approach focuses on the analysis of vulnerability based on variations in socioeconomic attributes of individuals and social groups. However, this conceptual approach fails to see the environmental factors that trigger vulnerability, because social groups having similar socioeconomic status can have different levels of vulnerability to environmental attributes and vice versa (Deressa 2010; Deressa et al. 2008).

The biophysical approach chiefly emphasizes on the vulnerability of the biophysical settings which is broadly used the natural hazards and climate change vulnerability studies (Füssel 2007). The approach generates the impact of the biophysical environment on human inhabitants (Liverman 1999). The impact is computed by distinguishing sensitivity indicators and determining the potential or actual hazards (Cutter et al. 2000). This approach, as suggested by Adger (1999), focuses on sensitivity to climate change and misses much of the adaptive capacity of people related to their capital assets.

The integrated assessment approach, on the other hand, combines the socioeconomic and biophysical approaches to measure the level of vulnerability. The framework, threat of an area by Cutter et al. (2000) and the biophysical approach of Füssel and Klein (2006) suggested that the interaction between the biophysical dimension and the social profile of communities (social dimensions) is studied as components of vulnerability. The adaptive capacity is also well-matched with the socioeconomic approach (Füssel 2007). Füssel (2007) and Füssel and Klein (2006) argued that the IPCC (2001) definition accommodates the integrated approach to vulnerability analysis-which conceptualizes vulnerability to climate change as a function of exposure, sensitivity, and adaptive capacity. The vulnerability mapping approaches of O'Brien et al. (2006), Feyissa et al. (2018), and Shawn et al. (2016) combine the biophysical and socioeconomic components as a function of exposure, sensitivity, and adaptive capacity to assess the level of vulnerability causations. The integrated vulnerability assessment 
approach includes the interactions among the components of vulnerability (exposure, sensitivity, and adaptive capacity) for the coupled human-environment systems (Turner et al. 2003). This study adopted the integrated approach to analyze rural household livelihood vulnerability to climate variability and extremes as a theoretical framework of livelihood vulnerability assessment.

The vulnerability analysis of this study follows the Third Assessment Report of IPCC expressed vulnerability as a function of exposure, sensitivity, and adaptive capacity (Schneider et al. 2001). As the vulnerability framework (Fig. 1) depicted, climate variability and extreme variables (exposure), biophysical and socioeconomic conditions (sensitivity), and adaptive capacity are components expecting to determine rural household's livelihood vulnerability level. The exposure variables: rate of change in rainfall variability, increasing in maximum and minimum temperature, and agricultural/meteorological drought frequency, are directly linked with the susceptible biophysical and socioeconomic components to determine households' livelihood vulnerability. The magnitude, frequency, timing, and duration of climate variability and extremes affect the rainfed agricultural livelihood activities of the study households. Physical attributes (topography, soil types, and land cover type) and human activities such as tillage systems, water management, resource depletion, and population pressure shaped the sensitivity of households to the livelihood vulnerability level (Fritzsche et al. 2014). At this juncture, the biophysical environments and socioeconomic variables such as slope/topography, population pressure, and accessibility to travel time with inadequate adaptive capacity influence the livelihood activities and increase the vulnerability of households. For instance, according to Fritzsche et al. (2014), heavy rainfall events in combination with steep slope vulnerability of soil to erosion will result in a direct impact of erosion and reduction of yield and loss of income as indirect impacts. The degree of adaptive capacity based on the sustainable livelihood capitals can determine the effect of exposure and sensitivity variables on households' livelihood vulnerability. The interaction of climate variability and extremes, biophysical and socioeconomic conditions, and adaptive capacity capitals determine overall households' livelihood vulnerability level.

\section{Methodology \\ Description of the study area}

South Wollo is one of the eleven administrative zones of the Amhara National Regional State (ANRSPC 2017). The absolute location of the zone ranges from $10^{\circ} 10^{\prime}-$ $11^{\circ} 41^{\prime} \mathrm{N}$ and $38^{\circ} 28^{\prime}-40^{\circ} 5^{\prime} \mathrm{E}$. It has six livelihood

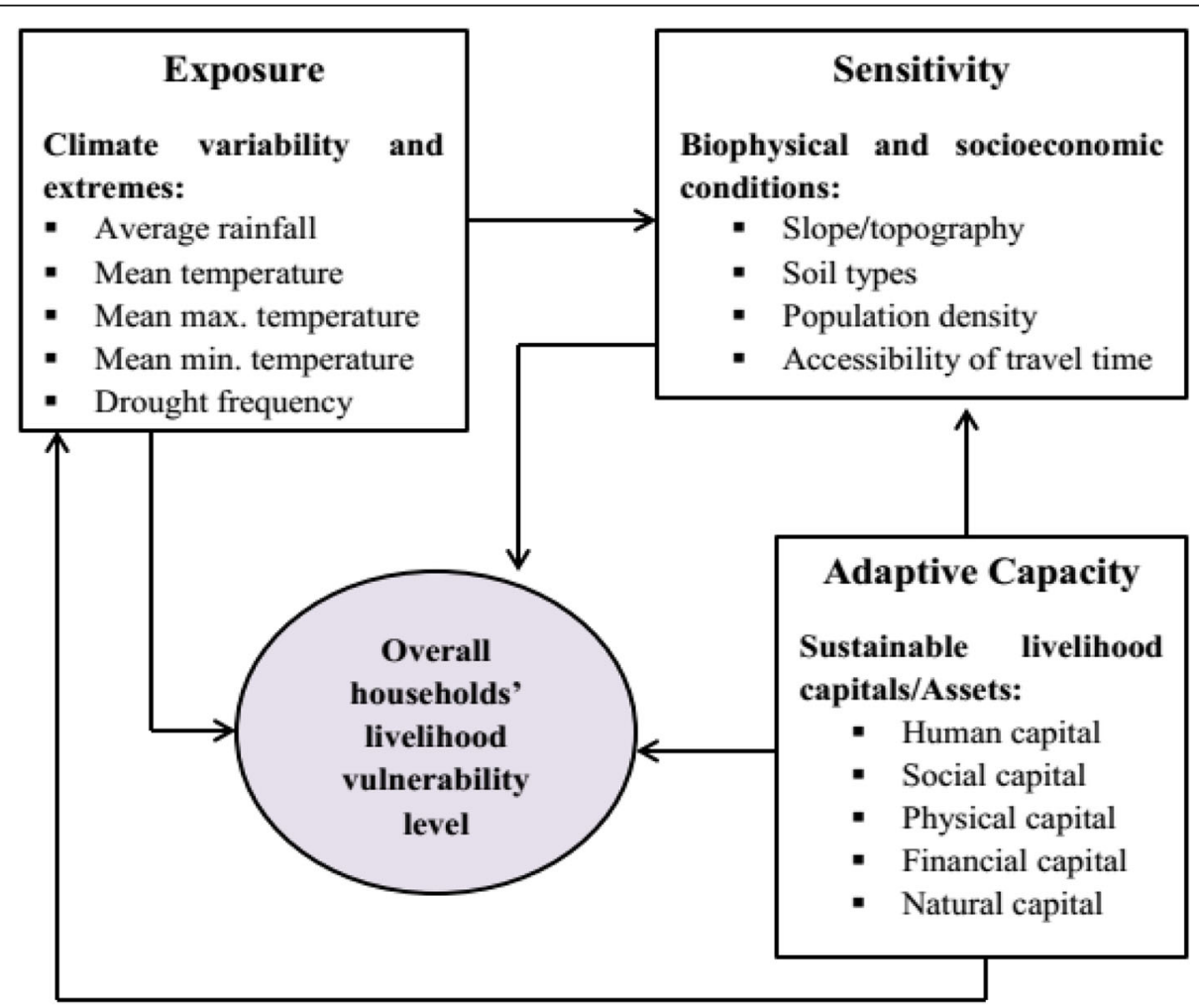

Fig. 1 A schematic diagram showing a set of predictor variables of exposure, sensitivity, and adaptive capacity to the overall households' livelihood vulnerability level 
zones, namely, Abay-Beshilo Basin (ABB), South Wollo and Oromia eastern lowland sorghum and cattle (SWS), Chefa Valley (CHV), Meher-Belg, Belg, and Meher (Fig. 2). Figure 3 indicates the elevation profile of the study. The proportion of area coverage of elevation dominating the study area is between 1600 and $3200 \mathrm{~m}$ altitude, which accounts about $14,357.56 \mathrm{~km}^{2}(82.67 \%)$ of the area. The other elevation ranges (920-1600, $3200-3800$, and 3800-4300 m) account for about 9.54\%, $7.3 \%$, and $0.5 \%$ respectively.

The rainfall and temperature of the study were shown spatial and temporal variation. The region under study is known as Kiremt dominant bimodal rainfall peaks: kiremt and belg (Lawrence et al. 2010). The highest peak rainfall of belg season (February to May) in the study was observed in April while the highest rainfall of Kiremt season (June to September) was observed in July and August (Fig. 4). Based on the long-term data (between 1901 and 2016), the average rainfall amount recorded ranges from the lowest value (15.13 and 18.04 $\mathrm{mm}$ ) in December and January to the highest value (264.78 and $270.50 \mathrm{~mm}$ ) in July and August. The mean, maximum and minimum temperatures also vary from the highest temperature values of 19.22, 26.6 and 11.82 ${ }^{\circ} \mathrm{C}$ in June to the lowest values of $14.68,22.93$ and $6.43{ }^{\circ} \mathrm{C}$ in December, respectively (Fig. 4). The drainage system of the study zone is the patterns formed by the streams, rivers and lakes (Fig. 5). The study zone is known by a number of large and small rivers that are categorized into two major drainage basins: Abay (the Blue Nile) and Awash (SWAD 2018). These two major drainage basins accounted for about $82 \%$ and $18 \%$ of the area respectively (SWAD 2018).

Different types of land use/land cover were observed in the study area (Table 1). Up-to-date land use/land cover information of 2016 was used that was extracted from Landsat image which was acquired from Water and Land Resource Center (WLRC) of Ethiogis-3 map server data catalog of 2019. Of the total land use/land cover, the cropland/agricultural land area accounted for the highest coverage of $7603.9 \mathrm{~km}^{2}$ (44\%). Conversely, the study area land covered by forest accounted for only about $1231 \mathrm{~km}^{2}(7 \%)$, which is below the national average of 17.2 million hectares $(15.5 \%$ of the national territory) (MoEFCC 2017).

The agricultural livelihood activities of the study for crop production follow Kiremt (big rainy season) and Belg rainfall, but vary between the livelihood zones. The old-style subsistence farming (a mix of both crop production and rearing of livestock) was the primary form of livelihood activities in all livelihood zones of the study area. The dominant crops cultivated across the study livelihood zones include barley, sorghum, teff, wheat, maize, lentils, faba beans, and haricot beans. Cattle, goats, sheep, and equines are the major livestock kept in widely different types of environment (Lawrence et al. 2010; USAID 2009). However, the contribution of livestock in the livelihood of people was highly limited by internal and external livestock diseases and parasites (USAID 2009; Little et al. 2006).

\section{Research design}

Mixed methods research design composed of quantitative and qualitative research methods were used for the study. The quantitative research methods were used to collect and analyze socioeconomic, rainfall, and temperature data. Opinions, suggestions, and perceptions of participants related to rural households' livelihood vulnerability to climate variability and extreme were collected and analyzed using qualitative research methods.

\section{Sampling techniques}

The study employed a multistage sampling technique to select kebeles (the lowest administrative unit in Ethiopia) and households across the livelihood zones. Stratified and proportional sampling techniques were used to select respondents from each livelihood zone. For that reason, the study area was firstly classified in to six livelihood zones: Abay-Beshilo Basin (ABB), South Wollo and Oromia eastern lowland sorghum and cattle (SWS), Chefa Valley (CHV), Meher-Belg, Belg, and Meher based on USAID (2009) classification. Secondly, identified kebeles found within their respective livelihood zone were selected using simple random sampling technique. The selected kebeles were Yewotet, Galemot, Mosebit, Tossa-felana, Ancharo, and Arejio from the livelihood zones of ABB, Meher, Belg, Meher-Belg, CHV, and SWS respectively. Thirdly, the samples $\mathrm{HHs}$ were selected using systematic random sampling procedures. In determining the sample size to fill the questionnaire, Kothari (2004) formula was employed as shown below (Eq. 1):

$$
n=\frac{Z^{2} * p * q * N}{e^{2}(N-1)+Z^{2} * p * q}
$$

where $n=$ the sample size; $N=$ total number of households; $p=0.5$ the sample proportion reliability and $q=1$ $-p ; e=5 \%$ the margin of error/acceptable error considered; $Z=1.96$ is the critical value for a $95 \%$ confidence interval.

Using the sample size formula, 361 respondents were determined from the six rural kebele administrative to fill the survey questionnaire. In the selection of key informants and FGD participants, long experience in farming, voluntary participation in the discussion, and knowledge about the impact of climate variability and extremes on their agricultural activities and productions were considered. In this regard, development agents 


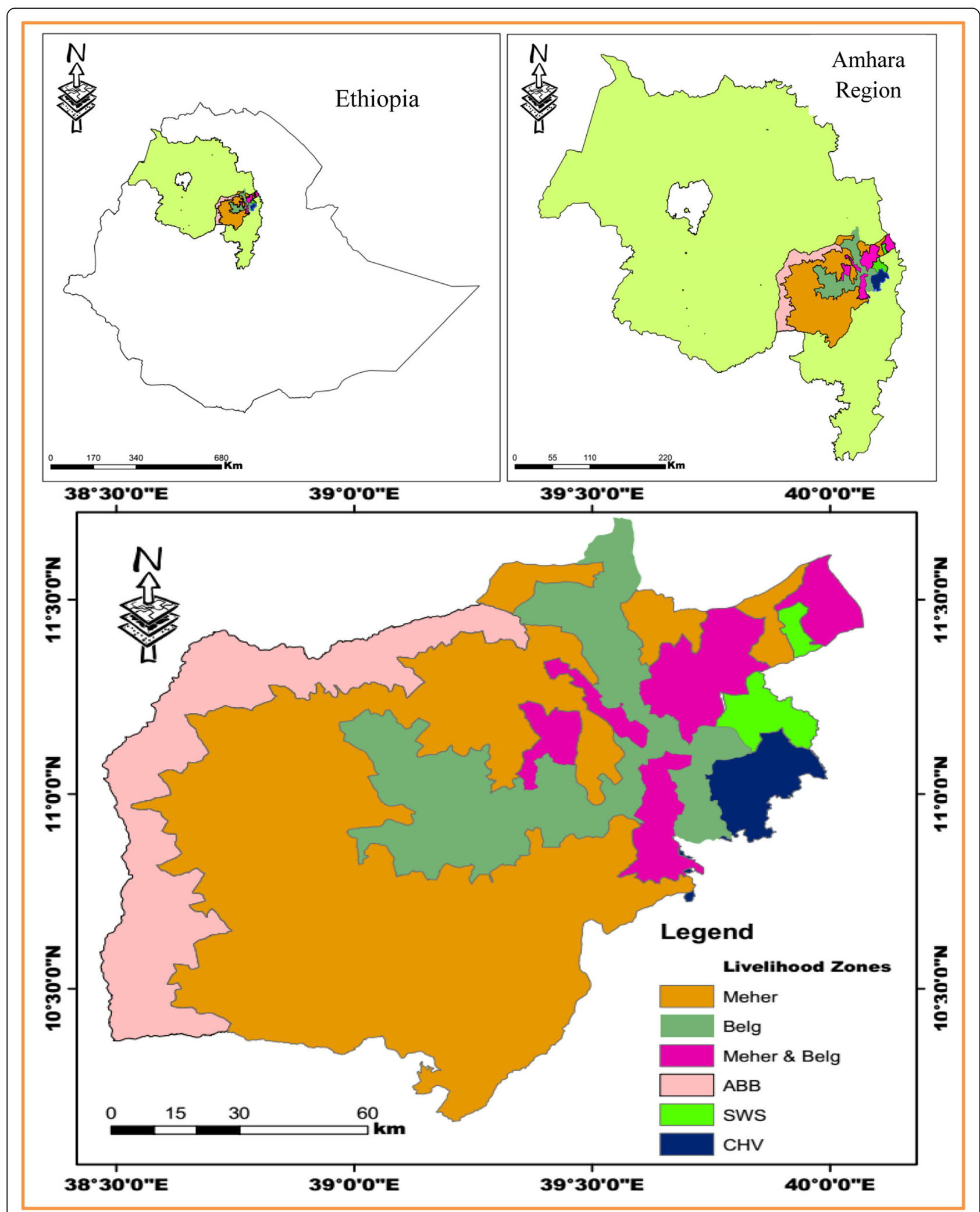

Fig. 2 The relative location and livelihood zone classifications of South Wollo administrative zone 


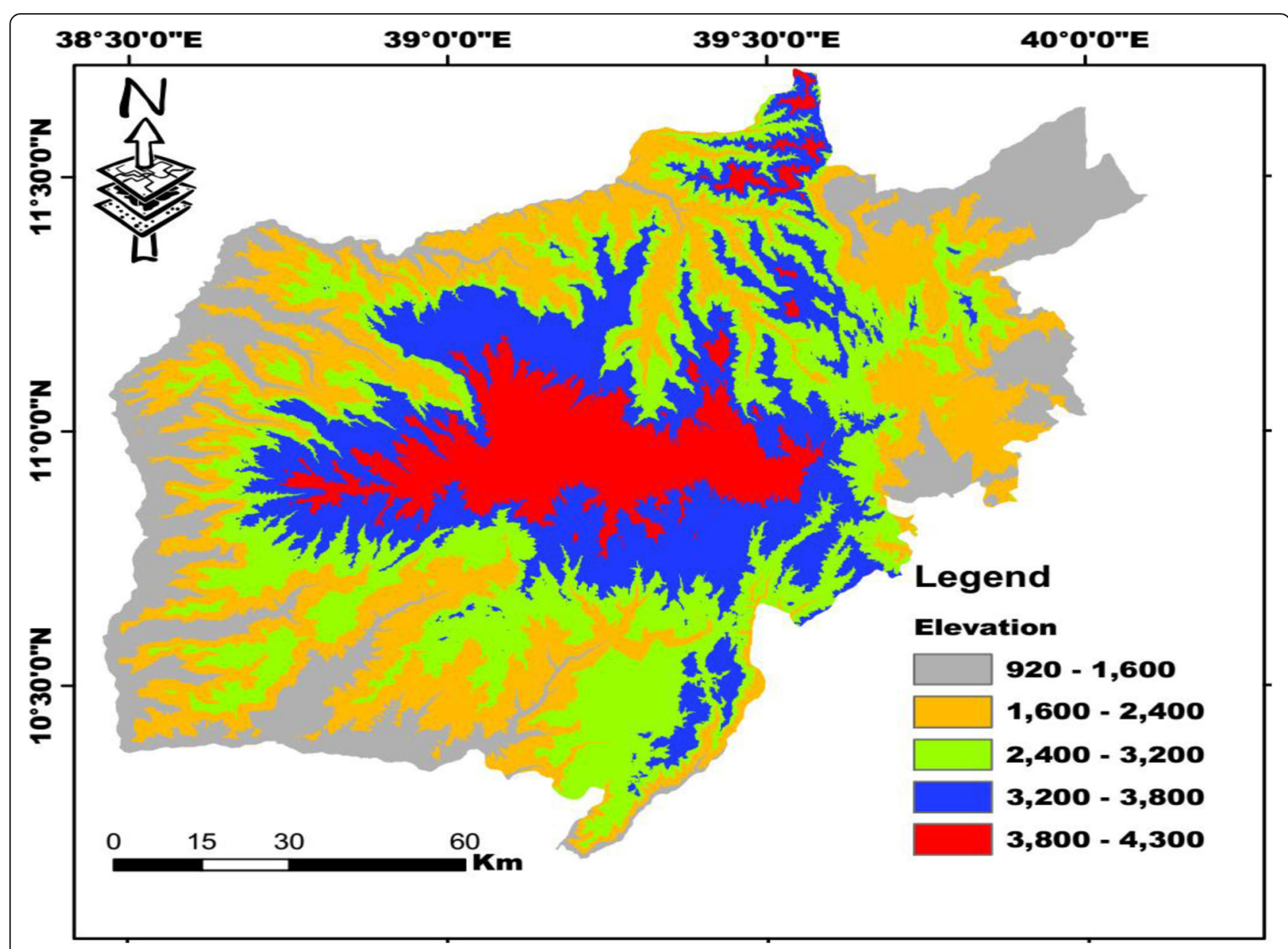

Fig. 3 The elevation classifications of South Wollo administrative zone

(DAs) helped in the selection of participants for the study. Purposively selected key informants include zone and district-level agricultural experts as well as DA workers and community leader of the farm households from the respective livelihood zone kebele. FGD participants are composed of male and female households, local community leaders, and development agents. A total of six FGDs were held. One FGD was conducted from each selected livelihood kebele, which comprised eight participants.

\section{Data sources and data collection techniques}

Both primary and secondary data sources were used for the study. Survey questionnaire, KI interview, and FGD were data collection instruments for the study. Using survey questionnaire, data were collected from $\mathrm{HH}$ heads using designed schedule. The survey questionnaires were constructed to handle inquires related to sample households' socioeconomic conditions, pattern of rainfall and temperature, and incidences of drought. The qualitative information from FGD and key informant interview were also conducted to enrich results of the survey. Unstructured interview guide checklists were prepared to frame the interview focused on the objectives of the study and allow flexibility for interviewees to talk freely as they wish. The information gathered comprises the condition of households' livelihood vulnerability in terms of the pattern of rainfall and temperature, drought frequency, the sensitivity of biophysical environment, and their level of adaptive capacity. The FGD was handled using developed unstructured generic questions as a guide. One FGD was conducted from each selected livelihood kebele. Rainfall and temperature data were obtained from the Ethiopian National Meteorological Agency (ENMA). The topography/slope of the area has been executed from the digital elevation model (DEM) with $30 \mathrm{~m}$ resolution. Soil types and soil erodibility as well as demographic related information were obtained from secondary data sources. Soil types and soil erodibility were accessed from FAO soil map and published documents while the demographic related information was accessed from the Central Statistical Agency, Ethiogis-3 data catalog information by Water and Land resource Center and government offices. 


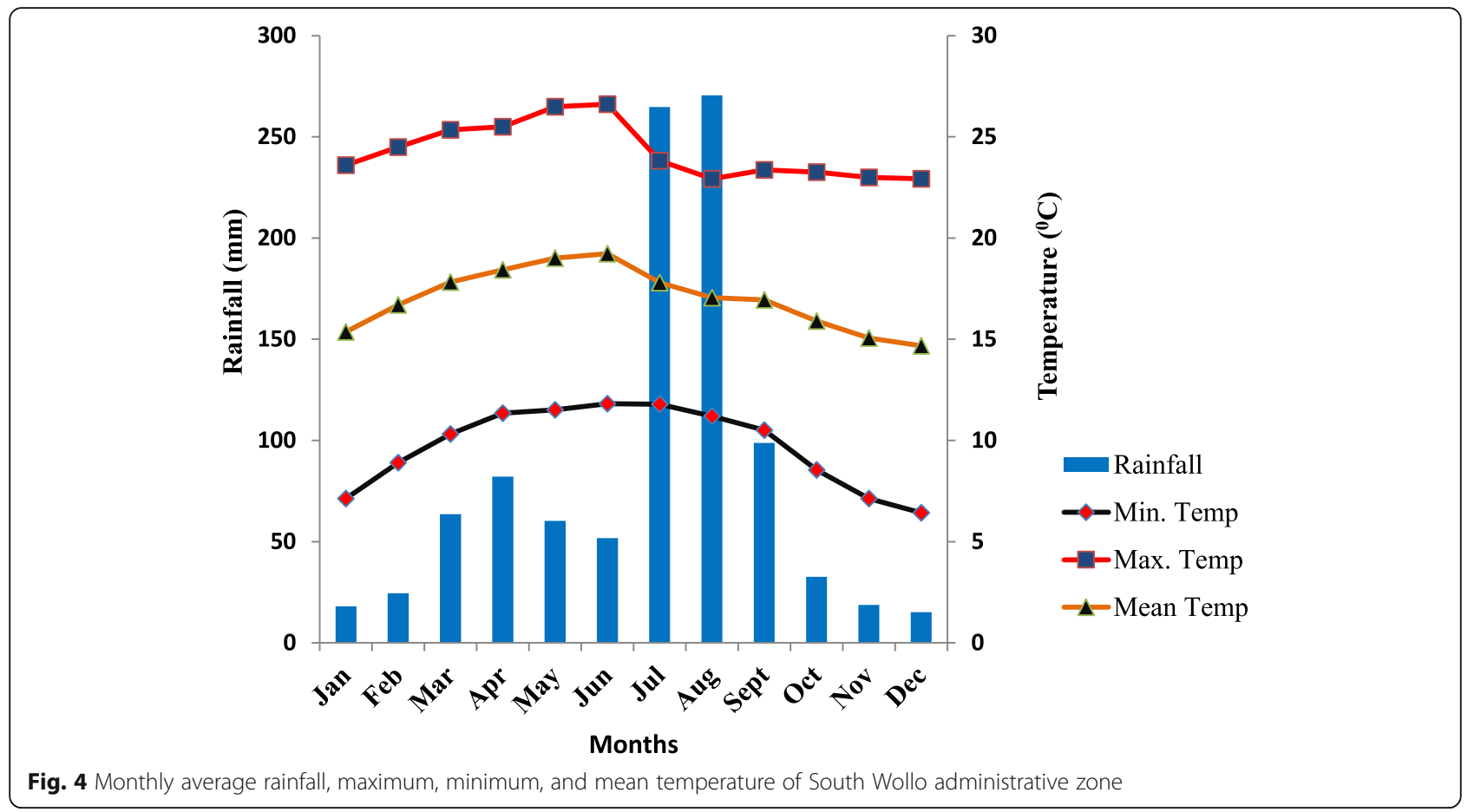

\section{Data analysis techniques}

\section{Constructing vulnerability assessment indices: climate} vulnerability index (CVI)

The study used CVI model to construct climate change vulnerability index by integrating indicators from Sullivan and Meigh (2005) and Sullivan and Byambaa (2013). CVI is a holistic, flexible, and interdisciplinary approach which integrates the physical, social, economic, and environmental issues. This study followed the three components of exposure, sensitivity, and adaptive capacity that integrated into the IPCC's definition of vulnerability as used in Sullivan and Meigh (2005), Sullivan and Byambaa (2013), and Feyissa et al. (2018). The computation of the composite index of CVI is shown in Eq. 2.

$$
C V I=\frac{\sum_{i=1}^{N} r i X i}{\sum_{i=1}^{N} r i}
$$

where CVI = Climate Vulnerability Index; $r_{i}=$ degree of risk weighting value associated with each component; $X_{i}=$ component $i$ of the CVI.

\section{Exposure}

Exposure represents the background climate conditions (variability and extreme events) and stimuli against which a system operates (Fritzsche et al. 2014). The attributes of climate variability and extreme stresses are explained in terms of the magnitude, frequency, duration, and areal extent of the hazard (IPCC 2001; O'Brien et al. 2006). In this study, indicators of exposure used to construct rural household livelihoods' vulnerability profile are related the historical changes in climate variables and the occurrence of extreme events. The average annual rainfalls, the average rate of changes in minimum and maximum temperature, and frequency of extreme events such as rainfall and drought over the period 19812017 were considered. The climate stressors of exposure variables/indicators will help to determine which individuals, social groups, and areas are more subjected and at higher risk of the direct effects (stimuli) of climate.

\section{Sensitivity}

Sensitivity is "the degree to which a system will be affected by, or responsive to, climate stimuli," i.e., how a system is likely to respond when exposed to a climateinduced stress (Smit et al. 2000; Nelitz et al. 2013). There are physical, economic, social, environmental, and cultural dimensions of sensitivity (Moss et al. 2001). Sensitivity typically shapes by natural and/or physical and human attributes which affect the physical constitution of a system (Fritzsche et al. 2014). The natural ecosystem (biophysical) and socioeconomic effects of climate change are broadly grouped under the sensitivity component (Tessema and Simane 2019; Mohan and Sinha 2010; Moss et al. 2001). The natural resource-based livelihood income of households or social groups from agriculture, livestock, and forest products increases the sensitivity as these sources are more dependent on climate. On the other hand, non-natural resource-based livelihood income sources that constituted salaried jobs, 


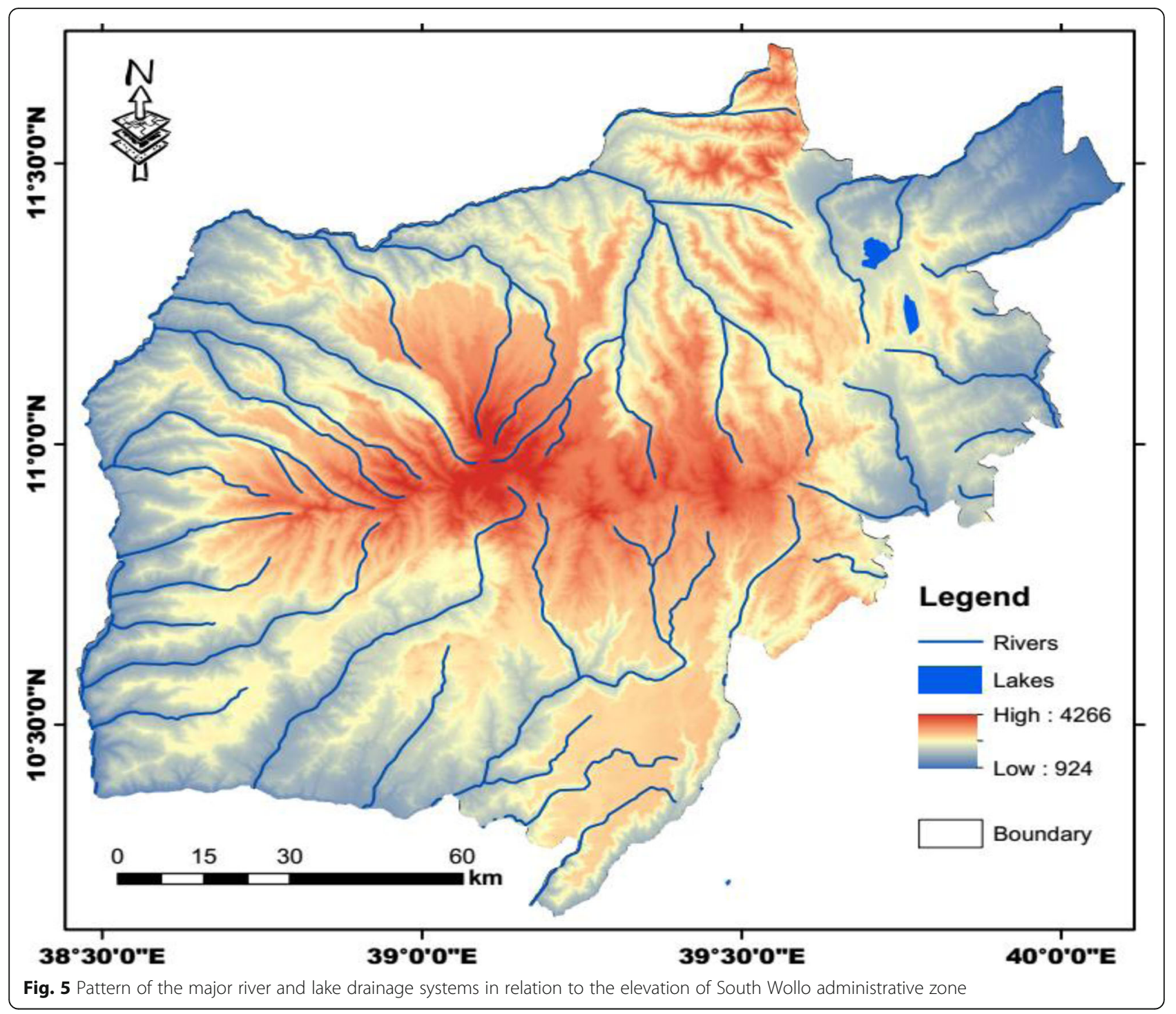

Fig. 5 Pattern of the major river and lake drainage systems in relation to the elevation of South Wollo administrative zone

Table 1 The land use and land cover type classification and area coverage of the study area

\begin{tabular}{lll}
\hline Land use and land cover types & Area $\left.\mathbf{( k m}^{\mathbf{2}}\right)$ & Coverage (\%) \\
\hline Forest & 1230.89 & 7.1 \\
Woodland & 1909.59 & 11.0 \\
Shrub/bush & 2030.96 & 11.7 \\
Crop/agricultural land & 7603.91 & 43.8 \\
Grassland & 2141.58 & 12.3 \\
Barren land & 2315.13 & 13.3 \\
Wetland & 0.13 & 0.0 \\
Water body & 39.44 & 0.2 \\
Afro alpine & 15.57 & 0.1 \\
Settlements & 78.53 & 0.5 \\
\hline
\end{tabular}

non-farm jobs, and remittances reduce the sensitivity (Ndungu et al. 2015). With the scope of this study, we have weighed and mapped the sensitivity of the local community using the biophysical (topography/slope, soil types, and their erodibility) and socioeconomic attributes such as accessibility travel time and population pressure/ density.

\section{Adaptive capacity}

Adaptive capacity is the potential or capability of a system to cope with the consequences of climate variability and extremes (Smit and Pilifosova 2003). Adaptive capacity indicators are based on assets and resources which reflect the Sustainable Livelihoods (SL) framework to comprehend better the factors affecting poor people's livelihoods (Defiesta and Rapera 2014). Hence, the commonly and widely accepted livelihood capitals for a number of adaptive capacity assessment of global 
livelihood literature include the natural, human, social, physical, and financial capitals (Ndungu et al. 2015; Ellis 2000). These adaptive capacity capitals are influencing the capability of individuals and communities access to and control over resources. Therefore, this study has worth and concentrates on the livelihood capitals as adaptive capacity (see Online resource for the full visualization of vulnerability components and indicators to their functional relationships with vulnerability).

Therefore, computation of vulnerability involves the identification of the exposure, sensitivity, and adaptive capacity of a system to climate variability and/or extremes. While the combination of the exposure and sensitivity can determine the potential impact (first-order vulnerability assessment), the adaptive capacity is the extent to which the potential negative impacts can be averted or derived benefits from the opportunities. Hence, vulnerability is viewed as a residual impact in terms of exposure $(E)$ plus sensitivity $(S)$ minus adaptive capacity $(A C)$. This study, therefore, uses the method employed by Downing et al. (2005) and Nelitz et al. (2013) in the computation of vulnerability using the components of exposure, sensitivity, and adaptive capacity as:

$$
\begin{aligned}
\text { Vulnerability }(\mathrm{V}) & =\text { Exposure }(\mathrm{E})+\operatorname{Sensitivity}(\mathrm{S}) \\
& \text {-Adaptive Capacity }(\mathrm{AC})
\end{aligned}
$$

\section{Normalization of indicators}

Multiple indicators will not be aggregated to a standard value of composite indicators unless normalized. As a result, the methodology used in UNDP (2016) for the computation of Human Development Index is followed to normalize indicator values of exposure, sensitivity, and adaptive capacity of the study. The normalized indicators' index of this study falls between 0 and 1 scale of standard values. Two types of functional relationships between the indicators and vulnerability are possible to construct the normalized indices: (i) vulnerability increase with increase (decrease) in the value of indicators. In this case, the normalization is done using Eq. 4.

$$
\mathrm{X}_{\mathrm{ij}}=\frac{\mathrm{X}_{\mathrm{ij}}-\operatorname{Min}\{\mathrm{Xij}\}}{\operatorname{Max}\{\mathrm{Xij}\}-\operatorname{Min}\{\mathrm{Xij}\}}
$$

(ii) The other functional relationship is assumed to be negative that vulnerability will decrease with increase in the values of indicators. In this case, the above (Eq. 4) normalizing score is computed using Eq. 5.

$$
\mathrm{X}_{\mathrm{ij}}=\frac{\operatorname{Max}\{\mathrm{Xij}\}-\mathrm{X}_{\mathrm{ij}}}{\operatorname{Max}\{\mathrm{Xij}\}-\operatorname{Min}\{\mathrm{Xij}\}}
$$

where $X$ represents the individual data point to be transformed/normalized in the distribution, $\operatorname{Min}\left(X_{i j}\right)$ is the minimum value in the distribution, and $\operatorname{Max}\left(X_{i j}\right)$ is the highest value of indicator in the distribution; $i$ is the livelihood zone, and $j$ is number of indicators. The values of the indicators have a positive relationship with vulnerability (while 0 being the lowest value and the least vulnerable area, 1 being the highest value and the most vulnerable).

\section{Assigning weights to indicators}

After computing the normalized scores, the index is constructed by giving weight to indicators. However, the basic question in constructing indices is the absence of standardized weights to each indicator. Basically, indicators are weighted using equal or unequal weighting schemes (Gebreegziabher et al. 2018). Weighting of indicators in this study uses an unequal method of Iyengar and Sudarshan (1982). This method is statistically sound and well suited for the development of a composite index of vulnerability to climate change as employed by Feyissa et al. (2018). The choice of the weights in this manner would also ensure that large variations in any one of the indicators would not excessively dominate the contribution of the rest of the indicators and distort inter regional comparisons (Iyengar and Sudarshan 1982). In Iyengar and Sudarshan's method, the weights are assumed to vary inversely as the variance over the regions in the respective indicators of vulnerability, i.e., the weight $w_{j}$ is determined using Eq. 6 .

$$
\mathrm{W}_{\mathrm{j}}=\mathrm{K} / \sqrt{\operatorname{Var}_{\mathrm{i}}\left(\mathrm{X}_{\mathrm{ii}}\right)}
$$

where $K$ is a normalizing constant and computed using Eq. 7.

$$
K=\left[\frac{1}{\sum_{j=1}^{j=m} \frac{1}{\sqrt{\operatorname{Var}_{i}\left(X_{i j)}\right)}}}\right]
$$

\section{Zonal statistics}

The application of the zonal statistics tool in ArcGIS is used in various studies in classifying and relating land surface in land use change (Youneszadeh et al. 2015; Rahmana 2016; Sierra-Soler et al. 2015). Recently in various studies, for instance, Feyissa et al. (2018) and Woodruff et al. (2017) used the application of the zonal statistics tool in ArcGIS to assess community vulnerability to climate variability and extreme events. The zonal statistics tool in ArcGIS was used in this study to assign values of indicators obtained from raster images to each livelihood zone. The summarized mean values for each livelihood zone were computed using the zonal statistical 
tool as a table. After the computation of the exposure, sensitivity, adaptive capacity components, and overall vulnerability indices, profiles were illustrated using maps, tables, and radar diagram. These figurative illustrations were with the scope to show multidimensional interaction and comparison of values for different category of variables across the livelihood zones.

\section{Results and discussion}

\section{Exposure component to livelihood vulnerability}

This component presents livelihood risk of rural households across the livelihood zones in view of climate variability and extreme exposure variables. In the assessment of agricultural livelihood vulnerability, indicators of the exposure component (rainfall, temperature, and frequency of drought events) at each livelihood zone were identified. These climate variability and extreme indicators of exposure component are commonly used in livelihood vulnerability exposure analyses. The identified indicators of exposure component are presented in Table 2. Accordingly, the deviation of rainfall ranges from about 105 to $194 \mathrm{~mm}$ in the livelihood zones. The rainfall normalized values for each livelihood zone were computed from the standard deviation of stations in the study. The results showed that Belg and Meher livelihood zones were found to be the highest level of rainfall exposure risk with the normalized values of 1.00 and 0.76 respectively. The highest range of temperature deviation $\left(1.21{ }^{\circ} \mathrm{C}\right)$ was identified with the minimum as compared to the average $\left(0.77{ }^{\circ} \mathrm{C}\right)$ and maximum $(0.92$ $\left.{ }^{\circ} \mathrm{C}\right)$ temperatures in the livelihood zones. Similar to the rainfall, the normalized values of the mean maximum and minimum temperature for each livelihood zone were computed from the normalized standard deviation of stations in the study. Accordingly, Belg and MeherBelg livelihood zones found to be the highest normalized average, maximum, and minimum temperature values. But, the remaining livelihood zones (CHV, SWS, and $\mathrm{ABB}$ ) showed the lowest values except $\mathrm{CHV}$ at maximum temperature. The respective mean drought frequency also varies from 8.14 to 6.91 in $\mathrm{ABB}$ and $\mathrm{CHV}$ livelihood zones. Based on the method of Iyengar and Sudarshan (Eq. 6), the attached weights for rainfall, average, maximum and minimum temperature, and frequency of drought exposure events were 0.199, 0.195, $0.188,0.214$, and 0.205 respectively.

The normalized scores were also reclassified into five equal probability weight interval (20\%) groups to characterize the various stages of exposure risk level to vulnerability in the livelihood zones. Accordingly, based on the weights, the overall livelihood zone level of exposure risk index (Table 2) indicates that high exposures were at Belg (0.71) and Meher (0.70). A moderate level of exposure risk index was observed at Meher-Belg (0.41) livelihood zone. The remaining livelihood zones (CHV and $\mathrm{ABB})$ and SWS have low (0.35 and 0.38) and very low (0.05) exposure risk levels. In addition to the results of the meteorological data, the FGD with households reported that their exposure to the change of different climate factors increased across the livelihood zones. Specifically, there is an increasing risk to the increasing temperature and variability of rainfall in the Meher and Belg livelihood zones. The analysis of meteorological data (in the past 37 years) showed a relatively high exposure risk in Meher and Belg livelihood zones due to high rainfall variability and increase of

Table 2 Normalized rainfall, temperature, drought frequency, and overall level of exposure risk across the livelihood zones of the study area

\begin{tabular}{|c|c|c|c|c|c|c|c|c|}
\hline \multirow{2}{*}{$\begin{array}{l}\text { Livelihood } \\
\text { Zones }\end{array}$} & \multirow{2}{*}{$\begin{array}{l}\text { Rainfall } \\
\text { Normalized }\end{array}$} & \multirow{2}{*}{$\begin{array}{l}\text { Averg. Temp. } \\
\text { Normalized }\end{array}$} & \multirow{2}{*}{$\begin{array}{l}\text { Max. Temp. } \\
\text { Normalized }\end{array}$} & \multirow{2}{*}{$\begin{array}{l}\text { Min. Temp. } \\
\text { Normalized }\end{array}$} & \multicolumn{2}{|c|}{ Drought Frequency } & \multicolumn{2}{|c|}{ Overall exposure risk } \\
\hline & & & & & Mean Freq. & Normalized & Normalized & Level of risk \\
\hline$A B B$ & 0.315 & 0.107 & 0.000 & 0.429 & 8.14 & 1.000 & 0.38 & Low \\
\hline Meher & 1.000 & 0.350 & 0.543 & 1.000 & 7.65 & 0.602 & 0.71 & High \\
\hline Belg & 0.759 & 1.000 & 0.595 & 0.591 & 7.59 & 0.602 & 0.71 & High \\
\hline Meher-Belg & 0.420 & 0.507 & 0.336 & 0.312 & 7.50 & 0.480 & 0.41 & Moderate \\
\hline $\mathrm{CHV}$ & 0.290 & 0.143 & 1.000 & 0.351 & 6.91 & 0.000 & 0.35 & Low \\
\hline SWS & 0.000 & 0.000 & 0.026 & 0.000 & 7.16 & 0.203 & 0.05 & Very low \\
\hline Variance & 0.129 & 0.134 & 0.144 & 0.111 & & 0.121 & & \\
\hline Root variance & 0.359 & 0.366 & 0.380 & 0.333 & & 0.349 & & \\
\hline 1/Root variance & 2.786 & 2.729 & 2.634 & 3.004 & & 2.869 & & \\
\hline Sum & 14.023 & & & & & & & \\
\hline K & 0.071 & & & & & & & \\
\hline W & 0.199 & 0.195 & 0.188 & 0.214 & & 0.205 & & \\
\hline
\end{tabular}

Note: Data of exposure indicators (rainfall, temperature, and frequency of drought) were derived from interpolated stations using zonal statistics in ArcGIS for each livelihood zones 
temperature. The view of the focus group discussants were also corroborating the variability of rainfall and increasing of temperature. The climate change exposure analysis made by Tessema and Simane (2019) and Feyissa et al. (2018) show that areas with the highest deviation in rainfall and temperature as well as frequency of drought events are more exposed and vulnerable. Moreover, studies of Stroosnijder (2009) and Araya et al. (2015) identified deficit and erratic nature of rainfall resulted in the vulnerability of Eastern African countries to low agricultural productivity and food shortages.

\section{Sensitivity component to livelihood vulnerability}

Four biophysical and socioeconomic indicators (slope, soil types, population density, and accessibility of travel time to social service centers) have been identified in the analysis of livelihood sensitivity based on the standards set by different scholars which were also used by Feyissa et al. (2018), Azene et al. (2018), and Teshome (2016). Accordingly, the higher sensitivity of livelihood zones to climate variability and extremes were derived from high population density, slope and inaccessibility to social service centers, and the erodibility nature of soil types. The slope of the study region is classified into five classes ranged from 0 to $2 \%$ (least sensitive) to $>30 \%$ (most sensitive) for land degradation and soil erosion (Fig. 6). The slope is an integral part of the land surface; it influences drainage, runoff, and erosion susceptibility. The assumption is that the higher slope value linked to the probability of high susceptibility of erosion and simultaneous reduction of soil depth. As can be seen in Table 3, 14, $980.5 \mathrm{~km}^{2}(86 \%)$ of the area was found above the slope of $8 \%$. Thus, the changes of maximum and minimum soil depth reduction factor were observed with increasing slope gradients. Moreover, the normalized value indicated that the $\mathrm{ABB}$ livelihood zone was experienced a

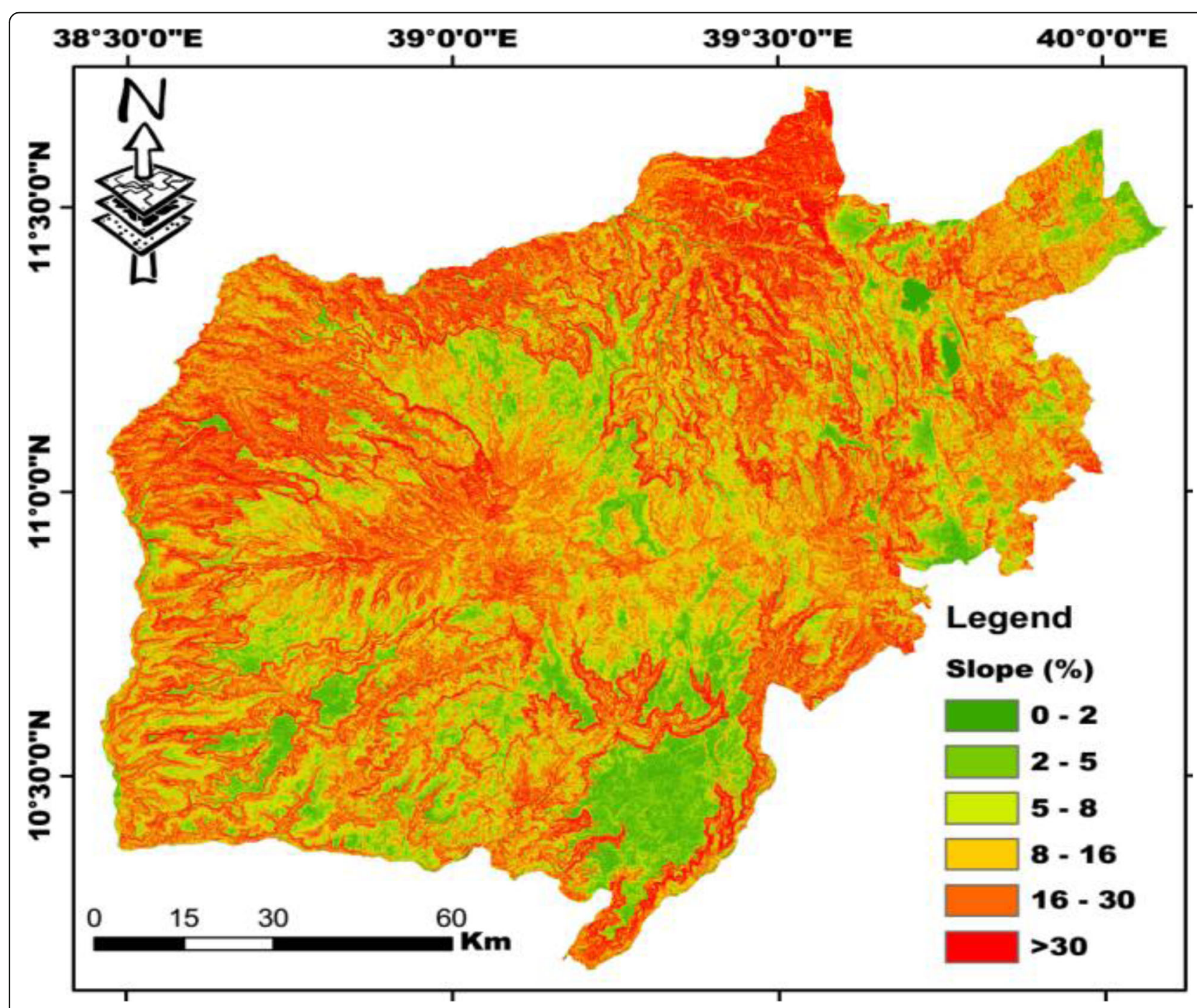

Fig. 6 The slope type classification and their spatial pattern of South Wollo administrative zone 
Table 3 Maximum and minimum soil depth reduction factor area coverage and description related to slope classes

\begin{tabular}{|c|c|c|c|c|}
\hline \multirow{2}{*}{$\begin{array}{l}\text { Slope } \\
\text { classes } \\
(\%)\end{array}$} & \multicolumn{2}{|l|}{ Reduction factors } & \multirow{2}{*}{$\begin{array}{l}\text { Covered } \\
\text { area }\end{array}$} & \multirow[t]{2}{*}{ Description } \\
\hline & Max. depth $\left(a^{*}\right)$ & Min. depth $\left(b^{*}\right)$ & & \\
\hline $0-2$ & 1.00 & 0.00 & $274(2 \%)$ & From flat to very gently sloping \\
\hline $2-5$ & 0.95 & 0.05 & $985(5 \%)$ & Gently sloping \\
\hline $5-8$ & 0.90 & 0.10 & $1078(6 \%)$ & Sloping \\
\hline $8-16$ & 0.80 & 0.20 & $2816(16 \%)$ & Strongly sloping \\
\hline $16-30$ & 0.70 & 0.30 & $4352(25 \%)$ & Moderately sloping \\
\hline$>30$ & 0.60 & 0.40 & 7860 (45\%) & Steep and very steep \\
\hline
\end{tabular}

Note: $\mathrm{a}^{*}$ and $\mathrm{b}^{*}$ are soil depth reduction factors related to slope classes in FAO data (1998)

very high sensitivity slope gradient (1.00). Moderate sensitivity of the slope was in the Belg livelihood zone (0.58). Low sensitivity of slope gradients was observed at SWS, Meher, and Meher-Belg livelihood zones with normalized values of $0.33,0.32$, and 0.29 respectively (Table 6). Studies of Hurni et al. (2015) and Liu et al. (2001) revealed that the erosion-resisting capacity and depth of soil generally decrease with the increasing of slope gradient due to loose soil stability, subsequently influence of land productivity, and crop yield.

The soil type associations found in the study are Leptosols, Calcaric Fluvisols, Haplic Xerosols, Eutric Nitisols and Regosols, Eutric and Vertic Cambisols, Pellic and Chromic Vertisols (Fig. 7). The dominant soil types in terms of areal coverage in the region are Cambisols, Leptosols, and Regosols with 11835.99, 2176.98 , and $1489.26 \mathrm{~km}^{2}$ respectively. These dominant soil types' agricultural viability is very limited as documented in different studies. FAO (1984) for example explained that both Cambisols and Regosols have limited agricultural value due to their shallow depth as they occur dominantly on the sloppy areas that are subject to severe erosion. Leptosols are also characterized by shallow depth underlined by hard rock and with less developed soil and coarse-textured (Feyissa et al. 2018).

It is believed that the susceptibility of soil type to erosion reduces the soil depth that influences the sensitivity of agricultural practices and ultimately affected the land efficiency of production. Based on Gelagay and Minale (2016) and Hurni et al. (2015), the attached average sensitivity of soil types to erosion (erodibility) due to the inherent characteristics are $0.30,0.25,0.23,0.23,0.20$, 0.20 , and 0.15 for Xerosols, Nitisols, Fluvisols, Regosols, Cambisols, Leptosols, and vertisols respectively (Table 4). Therefore, those major soil types (Cambisols, Regosols and Leptosols) are accounting for about $92 \%$ of the area. These soil types are categorized under high and moderate soil depth reduction (erodibility) related to their susceptibility to erosion in the region under study. The remaining soil types such as Xerosols, Nitosols, and Fluvisols are categorized under high level of erodibility class with the average $K$-factors ranged from 0.23 to 0.30 . Vertisols have the lowest level of erodibility class of 0.15 . At the level of livelihood zones, very high sensitivity on soil type erodibility was indicated at CHV with normalized values of 1.0 while moderate sensitivity $(0.5)$ was shown at Meher, Belg, and SWS livelihood zones. ABB and Meher-Belg livelihood zones were shown the least soil type erodibility (Table 4). Hurni et al. (2015) identified that soil depths were considered shallower in areas with soils more susceptible to erosion. Erosion sensitivity of Cambisols and Regosols are ranked as the most and intermediate susceptible soil types respectively (FAO 1991). Soil erosion in Ethiopia triggers the decline of agricultural productivity, food insecurity, and rural poverty (Gashaw et al. 2014; Lawrence et al. 2010).

The farmland suitability for agricultural practices in the study was characterized by the relative sensitivity indicators of slope, fertility, and rate of soil erosion. Such sensitivity attributes could be the source of vulnerability to the rural households mainly caused by land degradation problem. In relation to this, information obtained from the focus group discussants in $A B B$ livelihood zone perceived that the upside down nature of farmland, cutting of trees, and grazing and marginal land conversion to farmland increases the sensitivity of the biophysical environment. Discussants further mentioned that the farming households cultivated the outrageous steeply marginal areas using a digging hoe which is impossible to plough with a pair of oxen. According to them, such biophysical sensitivity impedes the agricultural productions and threatens the lives and livelihoods of rural households. Information obtained from Zonal and District agricultural offices on the other hand showed, the problem of land degradation and soil erosions are severe because of lower rate of water permeability coupled with steep slope exacerbated rural households' livelihood vulnerability. Indeed, MoWIE (2014) indicated that a soil erosion problem in the study area is one of the erosion hot spot areas of the Blue Nile river basin. 


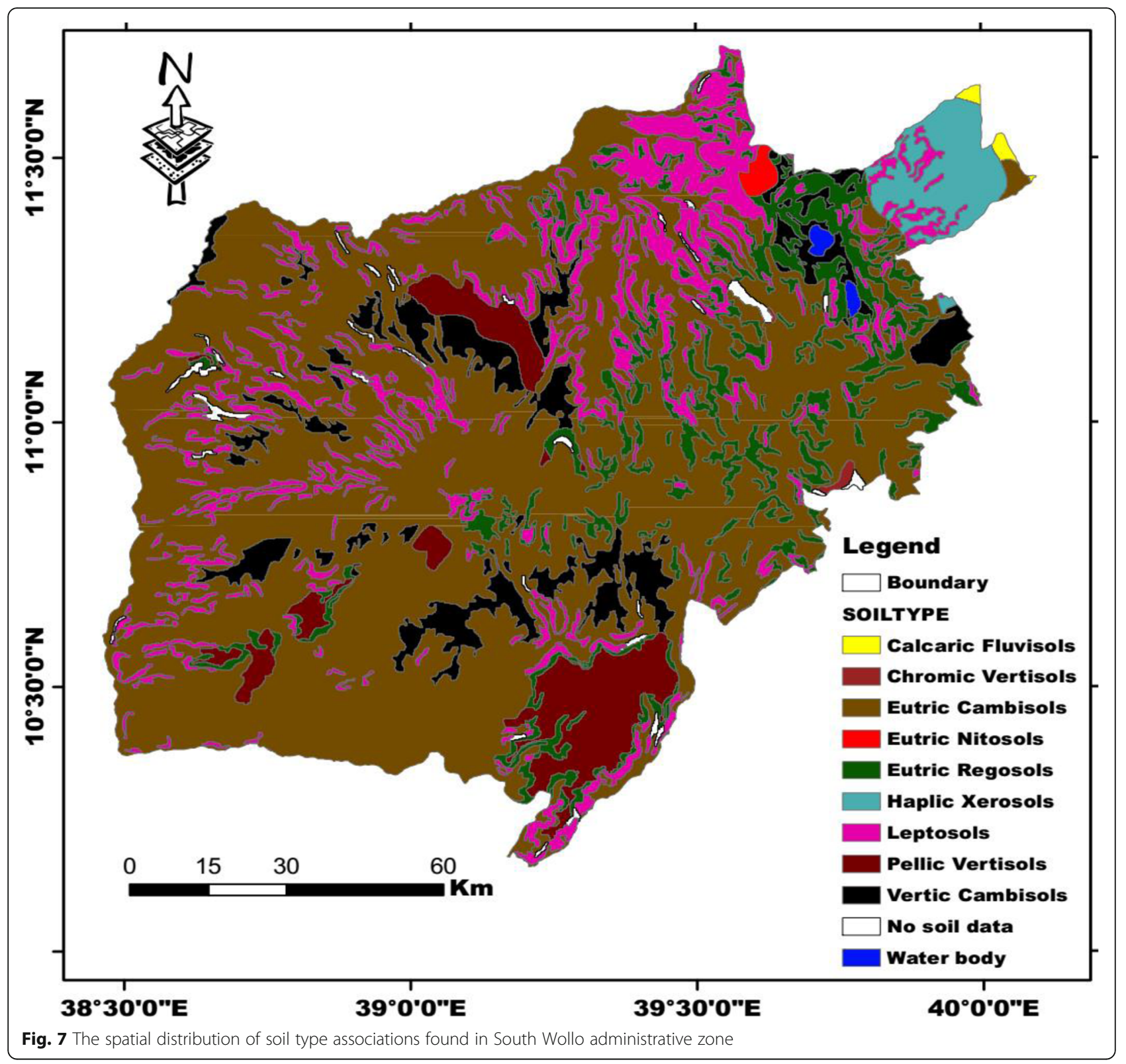

Table 4 Soil types area coverage and level of erodibility classes in relation to soil type erodibility (K-factor)

\begin{tabular}{llll}
\hline Soil types & Covered area & Average soil erodibility ( $\boldsymbol{K}$-factor) $\mathbf{a}^{*}$ & Level of erodibility classes \\
\hline Cambisols & $11836(70 \%)$ & 0.20 & Moderate \\
Leptosols & $2177(13 \%)$ & 0.20 & Moderate \\
Regosols & $1489(9 \%)$ & 0.23 & High \\
Vertisols & $963(6 \%)$ & 0.15 & Low \\
Xerosols & $401(2 \%)$ & 0.30 & High \\
Fluvisols & $3(0.02 \%)$ & 0.23 & High \\
Nitisols & $49(0.2 \%)$ & 0.25 & High \\
\hline
\end{tabular}


The socioeconomic sensitivity component indicators include accessibility and population density. The accessibility indicated as travel time is calculated using the cost-distance function of ArcGIS. The choices of the accessibility travel time, here used, are local settlements such as market places, schools, and health centers. The sensitivity varies among the livelihood zones in the accessibility of travel time in minutes (Fig. 8) to the service centers of market places, schools, and health institutions. Livelihood zones' sensitivity increases as the accessibility travel time increases to the service centers such as market places, schools, and health institutions. For instance, $\mathrm{ABB}$ and SWS livelihood zones have a very high and moderate accessibility travel time of 1.00 and 0.53 normalized values. Therefore, these livelihood zones were highly vulnerable due to inaccessibility of rural households to social services as compared to the others. The remaining livelihood zones showed very low and low normalized values of accessibility travel time (Table 5). Population pressure sensitivity to vulnerability also varies across the livelihood zones. Thus, the average high population densities were at SWS (226.5 persons $\left./ \mathrm{km}^{2}\right)$, Meher-Belg (212.8 persons $/ \mathrm{km}^{2}$ ), CHV (200.6 persons/ $\mathrm{km}^{2}$ ), and Belg (184.6 persons $/ \mathrm{km}^{2}$ ) livelihood zones (Table 5). The relatively high population density in these livelihood zones is also shown in Fig. 9. Hence, rural households residing in SWS, Meher-Belg, CHV, and Belg livelihood zones were highly vulnerable due to the attribute of high population density. Nyssen et al. (2015) and Dechassa et al. (2017) substantiated the impact of high population pressure for land degradation through reduced fallowing, conversion of forest and marginal steep slope areas into agricultural land. Based on the four indicators of sensitivity component, one final overall sensitivity risk levels with moderate and low sensitivity livelihood zones were identified. The attached weights to

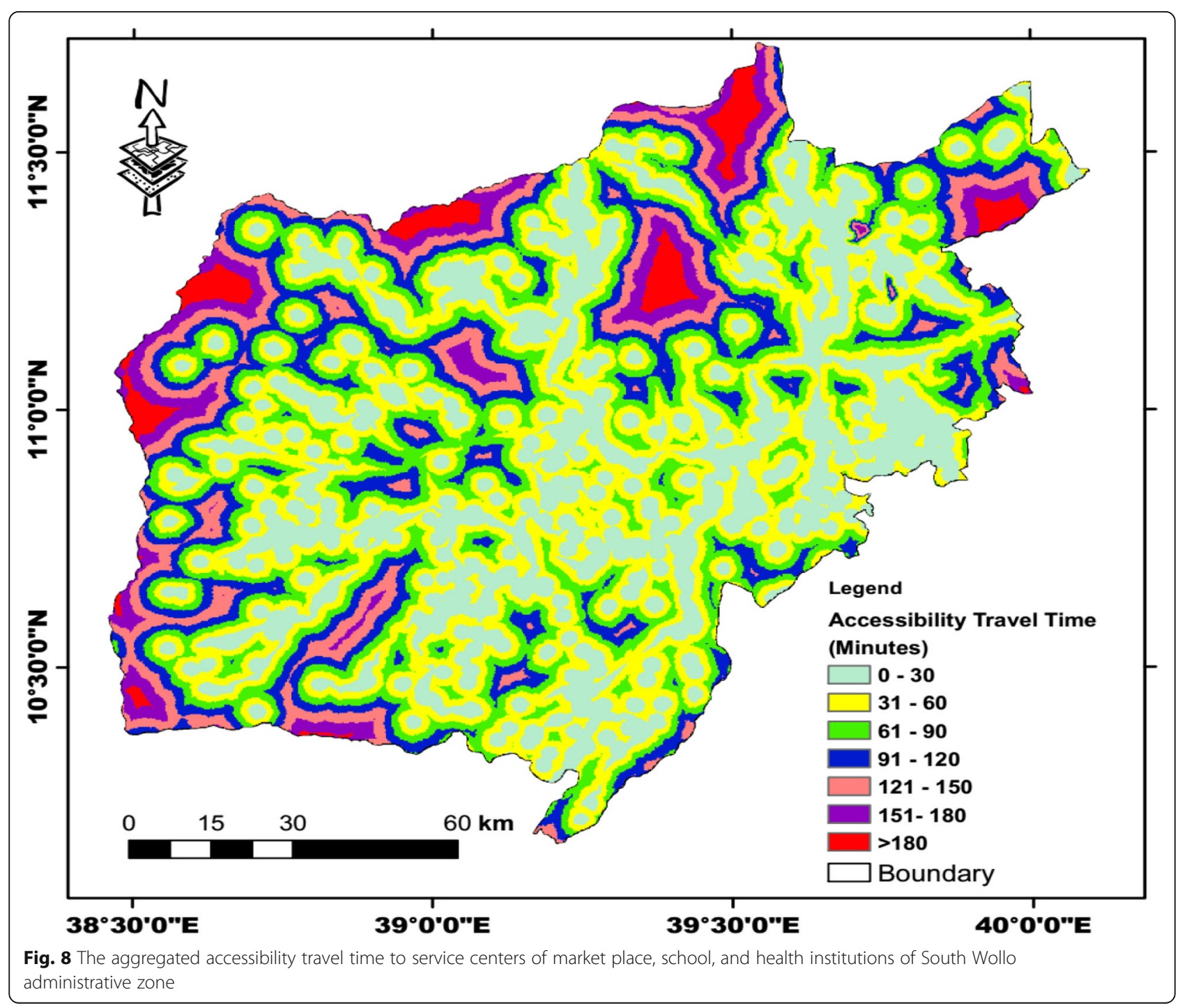


Table $\mathbf{5}$ Indicators of sensitivity and overall average sensitivity risk levels across the livelihood zones

\begin{tabular}{|c|c|c|c|c|c|c|c|c|c|c|}
\hline \multirow{3}{*}{$\begin{array}{l}\text { Livelihood } \\
\text { zones }\end{array}$} & \multicolumn{8}{|c|}{ Indicators of sensitivity } & \multirow{2}{*}{\multicolumn{2}{|c|}{$\begin{array}{l}\text { Overall average } \\
\text { sensitivity risk level }\end{array}$}} \\
\hline & \multicolumn{2}{|c|}{$\begin{array}{l}\text { Population } \\
\text { density*** }\end{array}$} & \multicolumn{2}{|l|}{ Slope } & \multicolumn{2}{|c|}{ Soil type erodibility } & \multicolumn{2}{|c|}{ Accessibility travel time } & & \\
\hline & Mean & Normalized & Mean(\%) & Normalized & $\begin{array}{l}\text { Mean Erodibility } \\
\text { factor }\left(a^{*}\right)\end{array}$ & Normalized & $\begin{array}{l}\text { Mean } \\
\text { (minutes) }\end{array}$ & Normalized & Normalized & $\begin{array}{l}\text { Level of } \\
\text { risk }\end{array}$ \\
\hline ABB & 71.1 & 0.00 & 37.55 & 1.00 & 0.20 & 0.00 & 76.77 & 1.00 & 0.50 & Moderate \\
\hline Meher & 134 & 0.41 & 30.19 & 0.32 & 0.21 & 0.50 & 42.76 & 0.10 & 0.33 & Low \\
\hline Belg & 184.6 & 0.73 & 33.01 & 0.58 & 0.21 & 0.50 & 46.27 & 0.19 & 0.50 & Moderate \\
\hline Meher-Belg & 212.8 & 0.91 & 29.78 & 0.29 & 0.20 & 0.00 & 44.46 & 0.14 & 0.33 & Low \\
\hline $\mathrm{CHV}$ & 200.6 & 0.83 & 26.68 & 0.00 & 0.22 & 1.00 & 39.12 & 0.00 & 0.46 & Moderate \\
\hline SWS & 226.5 & 1.00 & 30.23 & 0.33 & 0.21 & 0.50 & 59.05 & 0.53 & 0.59 & Moderate \\
\hline Variance & & 0.14 & & 0.12 & & 0.14 & & 0.14 & & \\
\hline Root variance & & 0.38 & & 0.34 & & 0.38 & & 0.38 & & \\
\hline $1 /$ Root varian & nce & 2.65 & & 2.95 & & 2.66 & & 2.66 & & \\
\hline Sum & & 10.91 & & & & & & & & \\
\hline K & & 0.09 & & & & & & & & \\
\hline W & & 0.24 & & 0.27 & & 0.24 & & 0.24 & & \\
\hline
\end{tabular}

the four sensitivity component indicators were 0.24 , $0.27,0.24$, and 0.24 , for population density, slope, soil type erodibility, and accessibility travel time, respectively. Based on the weights, the overall sensitivity risk levels were observed as moderately sensitivity index (0.46 to 0.59) at ABB, Belg, CHV, and SWS livelihood zones. Meher and Meher-Belg livelihood zones were on the other hand indicated as low sensitivity index of 0.33 (Table 5).

\section{Adaptive capacity component to livelihood vulnerability}

The availability of adaptive capacity assets is essential that enable the ability of human systems to adjust the impact of climate variability and extreme events. The adaptive capacity component of the study is composed of fifteen variables that fall in to the different asset forms of human, social, financial, physical, and natural for each livelihood zone (see Online resource for the full visualization of vulnerability components and indicators to their functional relationships with vulnerability). The analysis denoted that different levels of adaptive capacities were indicated at each of the livelihood zone. Details of the normalized and weights attached to adaptive capacity sub-component indicators as well as the overall average adaptive capacity level classification to climate variability and extreme events for each livelihood zone were presented in Table 6 and Fig. 10.

The first major sub-component of adaptive capacity was the human capital which includes three indicators: educational level, age dependence ratio and health status of households at the livelihood zone level. These indicators exhibited variation of human capital among the livelihood zones. Meher-Belg, Meher, and Belg livelihood zones have shown better educational and health status with lower age dependence ratio. Greater age dependence ratio coupled with lower education level and health services were observed in the livelihood zones of $\mathrm{ABB}$, SWS and CHV (Table 6). When all the sub-indicators were aggregated, Meher-Belg (0.68) and Meher (0.65) were at high human capital adaptive capacity levels. Belg (0.56) and ABB (0.50) were at a moderate level while CHV (0.34) and SWS (0.31) were at a low level of adaptive capacity. Similar findings made by Adu et al. (2018), Asrat and Simane (2017), and World Bank (2010) inferred that high age dependence ratio, limited access to health services, and lower level of educational level and training may stress household's adaptive capacity and mounting their vulnerability to climate variability and extreme induced risks.

The second major sub-component of adaptive capacity was the social capital. Variation of social capital capacity was observed among the livelihood zones (Table 6). Accordingly, in the informal insurance organization (Iddir/ Kire) participation, Meher, ABB, CHV, and Meher-Belg livelihood zones revealed the highest normalized values. In the labor sharing organizations (Mahiber, Wenfel, and Debbo/Jiggie), Meher, ABB, and Meher-Belg livelihood zones denoted the highest normalized values. Moreover, $\mathrm{CHV}$, SWS, and Meher livelihood zones were also the highest normalized values. When all indicators were 


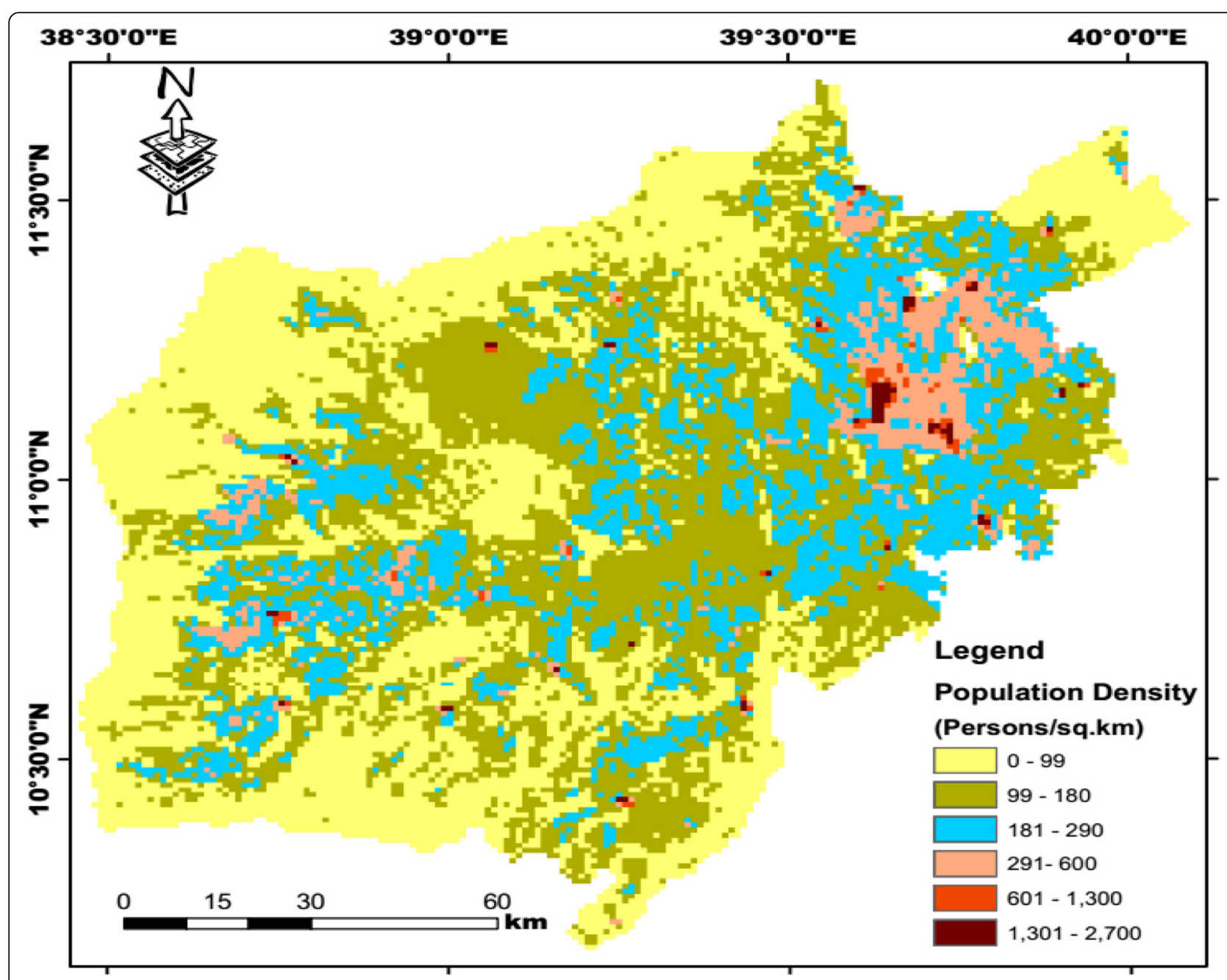

Fig. 9 The spatial distribution of population density in South Wollo administrative zone

aggregated, Meher (0.84), CHV (0.65), Meher-Belg (0.62), and $\mathrm{ABB}(0.52)$ were indicated from a very high to moderate level of adaptive capacity. On the other hand, Belg (0.19) and SWS (0.15) showed a very low level of adaptive capacity. Community institutions such as informal insurance organizations (Idir/Kire), labor sharing organizations (Mahiber, Wenfel and Debbo/Jiggie), and informal rotating savings association (Equib) are vital for linking ideas and resources, and increasing the adaptive capacity of people in time of immediate-induced disasters (Gebreegziabher et al. 2018; Arega 2013; World Bank 2010; Walker et al. 2001).

The third major sub-component of adaptive capacity in the study was that the physical capital comprises producer goods and infrastructure. Producer goods include the availability of technology components (farm inputs such as fertilizers, improved seeds, and extension services) and farm equipment (plowing instruments and farm animals). The infrastructure is the travel time access including access to road, school, and health services
(Table 6). These sub-component indicators of physical capital showed variation among the livelihood zones. Hence, the normalized values of Meher-belg, Meher, and Belg livelihood zones exhibited the highest in the availability of technology components and farm equipment. Better access to travel time also observed in $\mathrm{CHV}$ and Meher livelihood zones. When all the indicators of physical capital were aggregated, Meher (0.72), Meher-Belg (0.60), and CHV (0.57) were at high and moderate adaptive capacity levels. However, Belg (0.41), SWS (0.29), and $\mathrm{ABB}(0.00)$ were divulged low and very low adaptive capacity levels. In relation to the results, Gebreegziabher et al. (2018) and World Bank (2010) noted that limited access to physical infrastructure and unavailability of producer goods were matters that constrained to reduce sensitivity and to improve adaptive capacity of rural households.

The fourth major sub-component of adaptive capacity was the financial capital. In this study, the financial capital includes the livestock per capita owned (in TLU), 
Table 6 Normalized livelihoods' adaptive capitals and overall average level of adaptive capacity across the livelihood zones

\begin{tabular}{|c|c|c|c|c|c|c|c|c|c|c|c|c|c|c|c|c|c|}
\hline \multirow{3}{*}{ Livelihood zones } & \multicolumn{15}{|c|}{ Normalized livelihoods' adaptive capitals } & \multirow{2}{*}{\multicolumn{2}{|c|}{$\begin{array}{l}\text { Overall average } \\
\text { AC }\end{array}$}} \\
\hline & \multicolumn{3}{|c|}{ Human capital } & \multicolumn{3}{|c|}{ Social capital } & \multicolumn{2}{|c|}{ Physical capital } & \multicolumn{2}{|c|}{ Financial capital } & \multicolumn{5}{|c|}{ Natural capital } & & \\
\hline & 1 & 2 & 3 & 4 & 5 & 6 & 7 & 8 & 9 & 10 & 11 & 12 & 13 & 14 & 15 & 16 & Level of $A C$ \\
\hline$A B B$ & 0.00 & 1.00 & 0.50 & 0.86 & 0.71 & 0.00 & 0.00 & 0.00 & 0.20 & 0.06 & 0.00 & 0.00 & 0.53 & 0.68 & 0.37 & 0.30 & Low \\
\hline Meher & 0.55 & 0.51 & 0.88 & 1.00 & 1.00 & 0.53 & 0.90 & 0.53 & 0.80 & 1.00 & 0.12 & 0.31 & 0.75 & 0.48 & 0.67 & 0.68 & High \\
\hline Belg & 0.63 & 0.23 & 0.81 & 0.00 & 0.48 & 0.09 & 0.67 & 0.14 & 0.80 & 0.00 & 1.00 & 0.64 & 1.00 & 0.44 & 0.11 & 0.46 & Moderate \\
\hline Meher-Belg & 1.00 & 0.03 & 1.00 & 0.63 & 0.85 & 0.39 & 1.00 & 0.19 & 1.00 & 0.76 & 0.30 & 0.11 & 0.41 & 0.00 & 0.00 & 0.54 & Moderate \\
\hline $\mathrm{CHV}$ & 0.46 & 0.00 & 0.56 & 0.78 & 0.16 & 1.00 & 0.13 & 1.00 & 0.20 & 0.19 & 0.60 & 1.00 & 0.00 & 1.00 & 1.00 & 0.53 & Moderate \\
\hline SWS & 0.59 & 0.34 & 0.00 & 0.48 & 0.00 & 0.84 & 0.47 & 0.10 & 0.00 & 0.36 & 0.75 & 0.69 & 0.05 & 0.68 & 0.85 & 0.39 & Low \\
\hline Variance & 0.10 & 0.14 & 0.13 & 0.13 & 0.15 & 0.16 & 0.16 & 0.14 & 0.17 & 0.16 & 0.15 & 0.15 & 0.15 & 0.11 & 0.16 & & \\
\hline Root variance & 0.32 & 0.31 & 0.36 & 0.36 & 0.39 & 0.40 & 0.41 & 0.38 & 0.42 & 0.40 & 0.39 & 0.38 & 0.39 & 0.33 & 0.41 & & \\
\hline $1 /$ Root variance & 3.10 & 2.70 & 2.77 & 2.81 & 2.54 & 2.51 & 2.47 & 2.66 & 2.41 & 2.48 & 2.59 & 2.61 & 2.56 & 3.00 & 2.47 & & \\
\hline Sum & 39.68 & & & & & & & & & & & & & & & & \\
\hline K & 0.025 & & & & & & & & & & & & & & & & \\
\hline W & 0.08 & 0.07 & 0.07 & 0.07 & 0.06 & 0.06 & 0.06 & 0.07 & 0.06 & 0.06 & 0.07 & 0.07 & 0.07 & 0.08 & 0.06 & & \\
\hline
\end{tabular}

Note: Normalized values of Educational level (1), Dependence ratio (2), Health related problems (3), Iddir (4), Mahiber, Debbo \& Wenfel (5), Equib (6), Farm equipment and animals, improved seeds \& fertilizers (7), Travel time access (8), Livestock owned in TLU (9), Income source diversity (10), Access to saving \& credit services (11), Access to clean water (12), Forest as energy source (13), Farmland size owned (14), Perceived farmland degradation \& soil fertility (15), and Overall average adaptive capacity (16).

$A C$ adaptive capacity

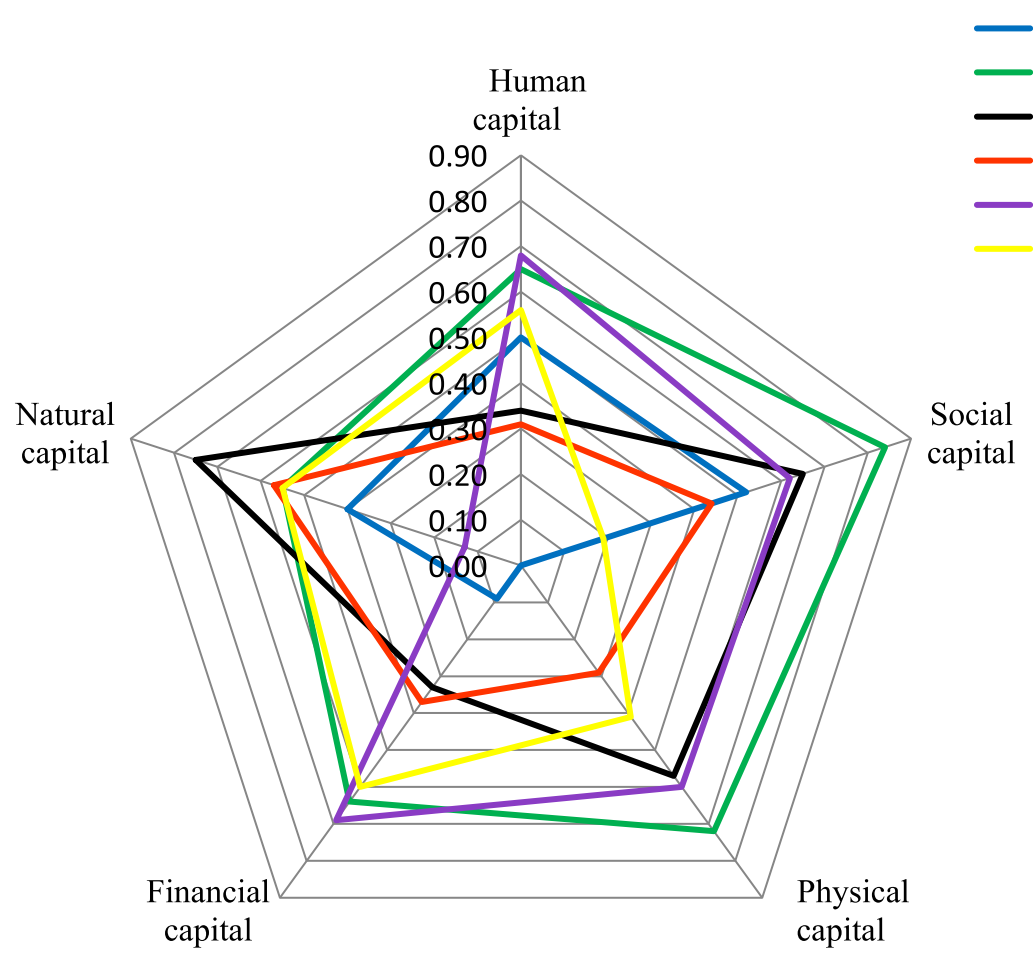

$\mathrm{ABB}$

Meher

$\mathrm{CHV}$

SWS

Meher-Belg

Belg

capital

capital

Fig. 10 The level of livelihood capitals for adaptive capacity at each livelihood zones using spider diagram 
diversity of income sources (sales of crop, livestock, firewood, and charcoal), safety nets, agricultural labor, paid employment in Towns (causal labor), and institutional access to saving and credit services (Table 6). The result showed that the livelihood zones of Meher-Belg, Meher, and Belg exhibited very high normalized values of livestock (in TLU) per capita owned, which means the adaptive capacity level is higher. The normalized values of Meher and Meher-Belg livelihood zones showed very high and high diversity of income sources respectively. When all the financial capital indicators were aggregated, Meher-Belg (0.69), Meher (0.64), and Belg (0.60) were relatively at high adaptive capacity levels. SWS (0.37) and $\mathrm{CHV}(0.33)$ were the lowest adaptive capacity levels while ABB (0.09) was at very low adaptive capacity level.

The fifth major sub-component of adaptive capacity was the natural capital. In this study, the natural resource capital involves the availability and access of water and forest resources, farmland size, perceived farmland degradation, and soil fertility across the livelihood zones. Consequently, CHV, SWS, and Belg livelihood zones showed higher adaptive capacity with better access either from rivers and streams or piped clean water. However, CHV, SWS, and Meher-Belg livelihood zones indicated the lowest adaptive capacity owing to the relative high utilization of forest as energy sources. Enhanced adaptive capacity with higher farmland size owned by the households was observed in livelihood zones of CHV, ABB, and SWS. This happens because higher farmland size provides an opportunity for crop diversification, soil conservation practices, and increasing crop yield which was also reported by O'Brien et al. (2006); Teshome (2016); Asrat and Simane (2017); and Tessema and Simane (2019). The average farmland size owned by households across the livelihood zones ranges from 1.44 ha at CHV to 0.69 ha at Meher-Belg. The average farmland size owned by a household was 0.96 ha, which is found to be almost equal to the regional average (1.0 ha) (Bluffstone et al. 2008; Arega 2013) and below the national (1.22 ha) level average farmland size owned (MoANR 2016; CSA 2012). Households' high level of adaptive capacity in the perceived farmland degradation and soil fertility was observed in CHV SWS and Meher livelihood zones. As indicated in USAID (2009), CHV SWS and Meher livelihood zones were consists of moderately fertile soil with alluvial, sandy, sandy clay, and sandy loam. It is apparent that when all the natural capital indicators were aggregated, CHV (0.75) was at high adaptive capacity levels. SWS (0.57), Meher (0.55), and Belg (0.55) were at moderate adaptive capacity levels. ABB (0.40) and Meher-Belg (0.13) were at low and very low adaptive capacity levels.

The overall attached weights based on the method of Iyengar and Sudarshan (Eq. 5), for human, social, physical, financial, and natural capitals are $0.27,0.19,0.16,0.18$, and 0.20 respectively. Based on the weights, one final overall adaptive capacity index is also present in Fig. 6 and Table 6, which suggests differences across the livelihood zones of the study. Among the livelihood zones, Meher (0.68) was the highest adaptive capacity index to climate variability and extreme events. Meher-Belg (0.54), CHV (0.53), and Belg (0.46) were at moderate adaptive capacity. SWS (0.39) and ABB (0.30) were at low adaptive capacity. The low level of adaptive capacity to the impact of climate variability and extremes was perhaps associated with the low level human, physical, and financial capitals.

The spider diagram (Fig. 10) also illustrated similar results in which the contribution of each livelihood capital indicators to the overall adaptive capacity component also spatially varies across the livelihood zones. In the diagram, the social capital contributes very high (0.84) normalized score to the adaptive capacity of Meher livelihood zone. High (0.6-0.8) normalized scores to the adaptive capacity of Meher and Meher-Belg livelihood zones were contributed from human, social, physical, and financial capitals. Similar normalized scores were also contributed from social and natural capitals to $\mathrm{CHV}$ and the financial capital to Belg livelihood zones. On the other hand, low (0.2-0.4) and very low (0.0-0.2) normalized score contributions to the adaptive capacity were also observed from the livelihood capitals. As a result, very low normalized scores to the adaptive capacity of $\mathrm{ABB}$ livelihood zone contributed from physical and financial capitals while social and natural capitals contributed to Belg and Meher-Belg livelihood zones respectively. Similarly, low normalized scores to the adaptive capacity of SWS livelihood zone contributed from all the livelihood capitals except natural capital while human and financial capital contributed to CHV livelihood zone.

\section{Vulnerability index: exposure, sensitivity, and adaptive capacity components}

Vulnerability was found to stem from a number of component factors. Rural households' livelihood vulnerability index per livelihood zones in the study was determined by the composite indicators of exposure, sensitivity, and adaptive capacity components (Table 7 and Fig. 11). Hence, both Belg and Meher found to be the highest exposure livelihood zones to vulnerability with an aggregated normalized exposure value of 0.71 . Equally, SWS, $\mathrm{ABB}$, Belg, and CHV livelihood zones showed moderate level of sensitivity to vulnerability (Table 7). Therefore, the highest level of exposure and sensitivity combined with a low level of adaptive capacity increased the vulnerability of SWS, ABB, and Belg livelihood zones as also reported by Tessema and Simane (2019) and Gebreegziabher et al. (2018). Vis-à-vis to this, Fig. 11 exhibits the 
Table 7 Normalized indices of exposure, sensitivity, and adaptive capacity across the livelihood zones

\begin{tabular}{llll}
\hline Livelihood zones & Normalized exposure & Normalized sensitivity & Normalized adaptive capacity \\
\hline ABB & 0.38 & 0.50 & 0.33 \\
Meher & 0.71 & 0.33 & 0.67 \\
Belg & 0.71 & 0.50 & 0.47 \\
Meher-Belg & 0.41 & 0.33 & 0.51 \\
CHV & 0.35 & 0.46 & 0.54 \\
SWS & 0.05 & 0.59 & 0.41 \\
Average & 0.44 & 0.45 & 0.49
\end{tabular}

livelihood zones' vulnerability index based on the normalized values of exposure, sensitivity, and adaptive capacity level. Thus, livelihood zone of Belg (0.75) was at a high level of vulnerability. ABB (0.57) and CHV (0.45) were at a moderate level of vulnerability. The SWS (0.37) was at a low vulnerability level. Meher-Belg (0.22) was the least vulnerable livelihood zone perhaps due to a high level of adaptive capacity such as infrastructure, asset accumulation, and social networks. High level of exposure to climate variability (rainfall and temperature) and extremes (drought) increases the vulnerability of rural households across livelihood zones. Likewise, the biophysical and socioeconomic sensitivity to vulnerability is exacerbated by topography/slope, poor soil fertility and high erodibility, population pressure, and increasing trends of environmental hazards like climate variability and droughts. The exposure to climate variability and extremes, biophysical and socioeconomic sensitivity with low adaptive capacity, lead communities to livelihood vulnerability across the livelihood zones are also reported by Feyissa et al. (2018), Callo-Concha and Ewert (2014), and Deressa et al. (2008).

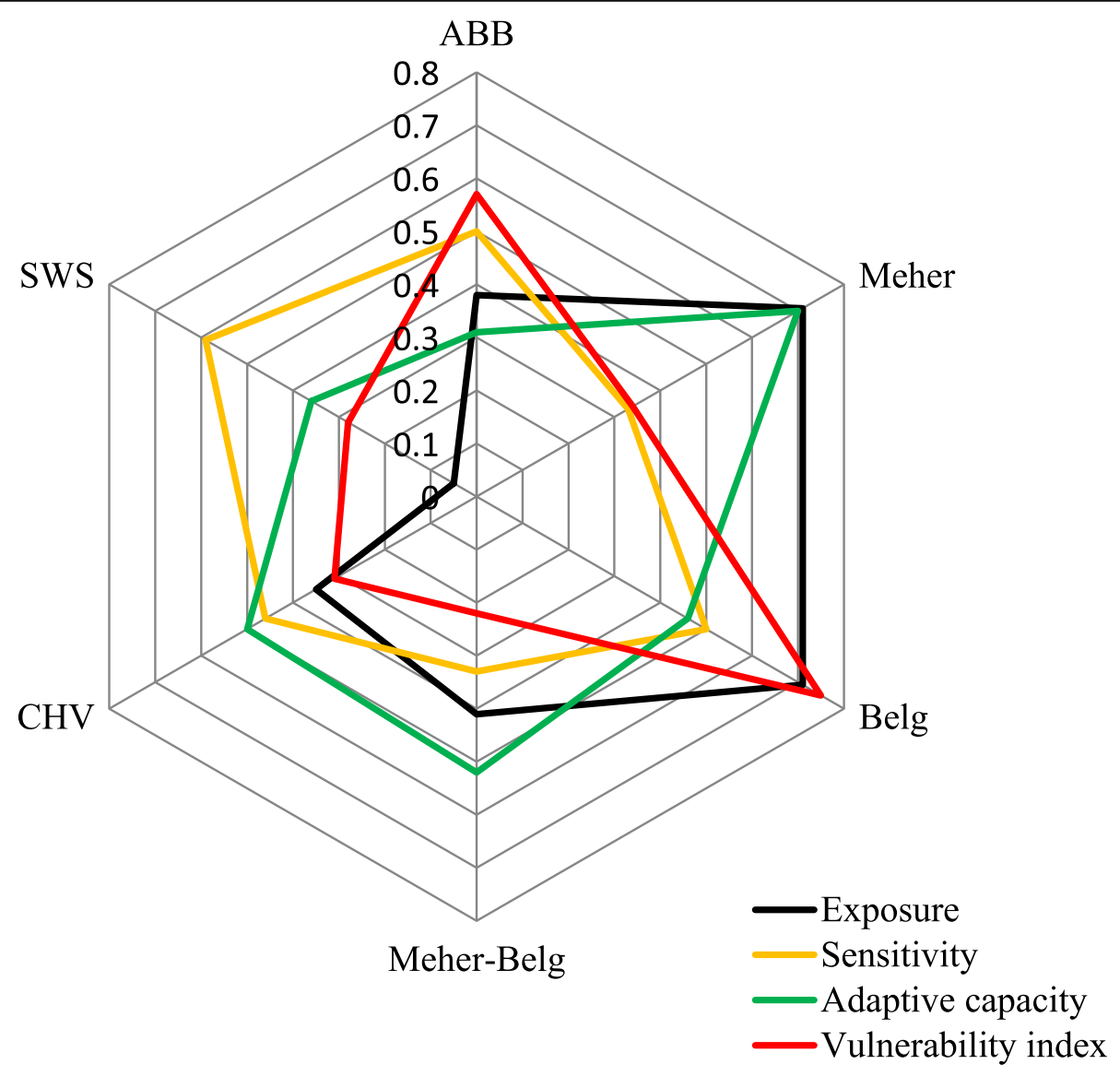

Fig. 11 Spider diagram showing livelihood zones' overall exposure, sensitivity, adaptive capacity, and vulnerability index 


\section{Conclusion}

Understanding and prioritizing areas and communities, which are the most vulnerable to climate variability and extremes, has become a growing concern for policymakers in order to develop area-specific adaptation strategies for sustainable development. In this regard, vulnerability assessment is a vital juncture in designing operational adaptation strategies. This study selects multiple indicators to quantify, map, classify, and prioritize the level of vulnerability in terms of the components of exposure, sensitivity, and adaptive capacity across the livelihood zones. It was identified that the exposure risk level of rural households varies among the livelihood zones. Accordingly, high vulnerability risk level was identified at Meher and Belg livelihood zones. However, SWS, ABB, Belg, and CHV livelihood zones revealed moderate level of sensitivity to vulnerability and MeherBelg was the least vulnerable livelihood zone perhaps due to high level of adaptive capacity such as infrastructure, asset accumulation, and social networks.

The vulnerability assessment of the study leads to construct a set of potential measures for specific geographical units and communities that will assist policymakers to design and implement appropriate adaptation strategies. This could help to diversify livelihood strategies suitable to each livelihood zone and adoption of farming technologies at a household/community level. The indicated strategies could reduce the sensitivity and exposure of the agricultural systems to climate calamity such as rainfall variability, erosion, and drought. In general, the findings of this study enhance adaptation strategies to the study livelihood zones and elsewhere in the country with greater exposure and sensitivity to climate variability and extremes. It is also empathized that applying Sullivan and Meigh's model following IPCC's approach for climate change analyses could be used concurrently for vulnerability assessment of diverse geographical regions and localities.

\section{Abbreviations \\ AfDB: African Development Bank; ANRSPC: Amhara National Regional State Plan Commission; CSA: Central Statistical Agency; CVI: Climate Vulnerability Index; ERI: Energy and Resources Institute; IPCC: Intergovernmental Panel on Climate Change; MoANR: Ministry of Agriculture and Natural Resources; MoEFCC: Ministry of Environment, Forest and Climate Change; MoWIE: Ministry of Water, Irrigation, and Electricity; SWAD: South Wollo Agriculture Department; UNDP: United Nations Development Program; USAID: United States Agency for International Development}

\section{Acknowledgements}

We are indebted to Bahir Dar and Debremarkos Universities for the financial support to the first author. We are also grateful to the Ethiopian National Meteorological Agency-East Amhara Meteorological service center (Kombolcha) for providing us the monthly rainfall and temperature data; the authors also greatly acknowledge rural households and zonal and district agricultural development agents across the livelihood zones for their willingness of providing the necessary information during data collection. We are also indebted to the two anonymous reviewers for their insightful and thoughtful feedback for further improvement of the manuscript.

\section{Authors' contributions}

The first author collected and analyzed the data and wrote the manuscript Both authors read, edited and approved the manuscript.

Funding

Bahir Dar and Debremarkos Universities.

Availability of data and materials

Not applicable

\section{Declarations}

Ethics approval and consent to participate

Not applicable.

\section{Consent for publication}

Not applicable.

\section{Competing interests}

The authors declare that they have no financial and non-financial competing interests.

Received: 29 October 2020 Accepted: 24 May 2021

Published online: 03 August 2021

\section{References}

Aberra K (2011) The impact of climate variability on crop production in Ethiopia: which crop is more vulnerable to rainfall variability. In: Ninth Conference of EEA. Ethiopian Economic Association, Addis Ababa

Abtew W, Melesse AM, Dessalegne T (2009) Spatial, inter and intra-annual variability of the Upper Blue Nile Basin rainfall. Hydrol Process 23(21):30753082. https://doi.org/10.1002/hyp.7419

Adger WN (1999) Social vulnerability to climate change and extremes in coastal Vietnam. World Dev 27:249-269

Adger WN, Brooks N, Bentham G, Agnew M, Eriksen S (2005) New indicators of vulnerability and adaptive capacity. Tyndall Centre for Climate Change Research, Norwich

Adu DT, Kuwornu JK, Anim-Somuah H, Sasaki N (2018) Application of livelihood vulnerability index in assessing smallholder maize farming households' vulnerability to climate change in Brong-Ahafo region of Ghana. Kasetsart J Soc Sci 39(1):22-32. https://doi.org/10.1016/j.kjss.2017.06.009

AfDB/African Development Bank (2003) Poverty and climate change: reducing the vulnerability of the poor through adaptation. World Bank, Washington, D.C

Allen K (2003) Vulnerability reduction and the community-based approach, natural disasters and development in a globalizing world. p 170

Amare A, Simane B (2017) Climate change induced vulnerability of smallholder farmers: agroecology-based analysis in the Muger sub-basin of the upper Blue-Nile basin of Ethiopia. Am J Climate Change 6(4):668-693. https://doi. org/10.4236/ajcc.2017.64034

ANRSPC/Amhara National Regional State Plan Commission (2017) Amhara national regional state plan commission 2015/2016 budget year annual statistical bulletin. Bahir Dar. Amhara Region Plan Commission.

Araya T, Nyssen J, Govaerts B, Deckers J, Cornelis WM (2015) Impacts of conservation agriculture-based farming systems on optimizing seasonal rainfall partitioning and productivity on vertisols in the Ethiopian drylands. Soil Tillage Res 148:1-13. https://doi.org/10.1016/j.still.2014.11.009

Arega B, (2013) Determinants of rural household food security in drought prone area of Ethiopia: Case study in Lay-Gaint District, Amhara Region. PhD dissertation, unpublished. University of South Africa, South Africa.

Asrat P, Simane B (2017) Characterizing vulnerability of crop-based rural systems to climate change and variability: agro-ecology specific empirical evidence from the Dabus watershed, North-West Ethiopia. Am J Climate Change 6(4): 643-667. https://doi.org/10.4236/ajcc.2017.64033

Azene YB, Zeleke MT, Chekole AB (2018) Mountain communities vulnerability to climate change and natural resources scarcity in Northwest Ethiopia: the case of Debark Woreda. J Degraded Mining Lands Manage 6(1):1467-1482. https://doi.org/10.15243/jdmlm.2018.061.1467

Bewket W (2009) Rainfall variability and crop production in Ethiopia: case study in the Amhara region. In: Proceedings of the 16th International Conference of Ethiopian Studies, vol 3. Norwegian University of Science and Technology, Trondheim, pp 823-836 
Bluffstone R, Yesuf M, Bushie B, Damite D (2008) Rural livelihoods, poverty, and the Millennium Development Goals. Evidence from Ethiopian survey data. Environment for Development Initiative. Discussion Paper Series.

Callo-Concha D, Ewert F (2014) Using the concept of resilience, vulnerability and adaptability for the assessment and analysis of agricultural systems. Change Adaptation Socio-Ecol Syst 1(1):1-11. https://doi.org/10.2478/cass-2014-0001

Challinor A, Wheeler T, Garforth C, Craufurd P, Kassam A (2007) Assessing the vulnerability of food crop systems in Africa to climate change. Climatic Change 83:381-399

CSA/Central Statistical Agency (2012) Agricultural sample survey 2011/2012, volume IV: report on land utilization. Central Statistical Agency, Addis Ababa

Cutter SL, Mitchell JT, Scott MS, (2000) Revealing the vulnerability of people and places: a case study of Georgetown County, South Carolina. Ann Assoc Am Geogr 90(4):713-737

Daley B (2015) Environmental Issues in Ethiopia and Links to the Ethiopian Economy. https://doi.org/10.12774/eod_hd.september2015.daleyb

Daze A, Ambrose K, Ehrhart C, (2009) Climate vulnerability and capacity analysis handbook. Care International, Geneva, Switzerland.

Dechassa C, Simane B, Alamirew B (2017) Farmers' livelihoods vulnerability to climate variability and change in Didesa Basin southern part of Abay Basin, Ethiopia. In: Climate Change Adaptation in Africa, pp 267-284. https://doi. org/10.1007/978-3-319-49520-0_17

Defiesta G, Rapera C (2014) Measuring adaptive capacity of farmers to climate change and variability: Application of a composite index to an agricultural community in the Philippines. J Environ Sci Manage 17(2):48-62

Deressa T (2010) Assessment of the vulnerability of Ethiopian agriculture to climate change and farmers' adaptation strategies. Thesis. University of Pretoria

Deressa T, Hassan RM, Ringler C (2008) Measuring Ethiopian farmers' vulnerability to climate change across regional states. International Food Policy Research Institute (IFPRI) Discussion Paper 00806

Deressa TT, (2007) Measuring the economic impact of climate change on Ethiopian agriculture: Ricardian approach. CEEPA Discussion Paper No. 25. Centre for Environmental Economics and Policy in Africa, The World Bank

Doll P (2009) Vulnerability to the impact of climate change on renewable groundwater resources: A global-scale assessment. Environ Res Lett 4:035006. https://doi.org/10.1088/1748-9326/4/3/035006

Downing TE, Patwardhan A, Klein RJ, Mukhala E, Stephen L, Winograd M, Ziervogel G, (2005) Assessing vulnerability for climate adaptation. Cambridge University Press, Cambridge, UK

Dyoulgerov M, Bucher A, Zermoglio F, Forner C (2011) Climate risk and adaptation country profile. Ethiopia: vulnerability, risk reduction and adaptation to climate change. Global Facility for Disaster Reduction and Recovery, World Bank, Washington, DC.

Edame GE, Ekpenyong AB, Fonta WM, Duru EJ, (2011). Climate change, food security and agricultural productivity in Africa: Issues and policy directions. International Journal of Humanities and Social Science, 1(21), 205-223. Centre for Promoting Ideas, USA.

Ellis F, (2000). Rural livelihoods and diversity in developing countries. Oxford University press, England, UK.

ERI/Energy and Resources Institute (2006) Adaptation to Climate Change in the Context of Sustainable Development. available at http://www.teriin.org/ events/docs/adapt. Accessed Apr 2017

FAO (1984). Assistance to Land Use Planning Ethiopia: Provisional Soil Association Map Of Ethiopia (1:2 000 000). Report prepared for the Government of Ethiopia by the Food and Agricultural Organization of the United Nations acting as executing agency for the United Nations Development Program.

FAO (1991). World Soil Resources. An explanatory note on the FAO World Soil Resources Map at 1: 25,000,000. World Soil Resources Report no. 66. Food and Agriculture Organization of the United Nations, Rome, Italy.

Fellmann T, (2012). The assessment of climate change-related vulnerability in the agricultural sector: reviewing conceptual frameworks. In Building resilience for adaptation to climate change in the agriculture sector. Proceedings of a Joint FAO/OECD, 37-61. 37-61. Food \& Agriculture Org, Rome.

Feyissa G, Zeleke G, Gebremariam E, Bewket W (2018) GIS based quantification and mapping of climate change vulnerability hotspots in Addis Ababa. Geoenviron Disasters 5(1):14. https://doi.org/10.1186/s40677-018-0106-4

Fritzsche K, Schneiderbauer S, Bubeck P, Kienberger S, Buth M, Zebisch M, Kahlenborn W (2014) The Vulnerability Sourcebook: Concept and guidelines for standardised vulnerability assessments

Füssel H (2007) Vulnerability: a generally applicable conceptual framework for climate change research. Glob Environ Change 17(2):155-167
Füssel HM, Klein RJT (2006) Climate change vulnerability assessments: an evolution of conceptual thinking. Climatic Change 75(3):301-329

Gallopín GC (2006) Linkages between vulnerability, resilience, and adaptive capacity. Glob Environ Change 16(3):293-303. https://doi.org/10.1016/j. gloenvcha.2006.02.004

Gashaw T, Amare B, Silassie HG (2014) Land degradation in Ethiopia: causes, impacts and rehabilitation techniques. J Environ Earth Sci 4(9):98-104

Gautam M (2006) Managing drought in sub-Saharan Africa: Policy perspectives. Invited paper prepared for presentation at the International Association of Agricultural Economists. Gold Coast, Australia

Gebreegziabher Z, Mekonnen A, Bekele RD, Bane J, Zewdie SA, (2018) Mapping vulnerability to climate change of the farming sector in the Nile Basin of Ethiopia: a micro-level perspective. In Agricultural Adaptation to Climate Change in Africa. 28(54), 28-54. Routledge, England, UK.

Gelagay HS, Minale AS (2016) Soil loss estimation using GIS and remote sensing techniques: a case of Koga watershed, Northwestern Ethiopia. Int Soil Water Conserv Res 4(2):126-136. https://doi.org/10.1016/j.iswcr.2016.01.002

Gizachew L, Shimelis A (2014) Analysis and mapping of climate change risk and vulnerability in Central Rift Valley of Ethiopia. African Crop Sci J 22:807

Herrmann SM, Anyamba A, Tucker CJ (2005) Recent trends in vegetation dynamics in the African Sahel and their relationship to climate. Glob Environ Change 15(4):394-404

Hulme M, Doherty R, Ngara T, New M, Lister D (2001) African climate change: 1900-2100. Climate Res 17(2):145-168. https://doi.org/10.3354/cr017145

Hurni K, Zeleke G, Kassie M, Tegegne B, Kassawmar T, Teferi E, ... Kebebew Z (2015) Economics of Land Degradation (ELD) Ethiopia case study: Soil degradation and sustainable land management in the rainfed agricultural areas of Ethiopia: an assessment of the economic implications. Report for the Economic of Land Degdradtion Intiative

IPCC/Intergovernmental Panel on Climate Change (2001) Climate Change 2001 Impacts, Adaptation, and Vulnerability. Contribution of Working Group II to the Third Assessment Report of the Intergovernmental Panel on Climate Change.

IPCC/Intergovernmental Panel on Climate Change (2007) Climate change 2007 synthesis report. Contribution of working groups I, II and III to the fourth assessment report of the intergovernmental panel on climate change, pp $95-212$

IPCC/Intergovernmental Panel on Climate Change (2014) Climate change 2014 impacts, adaptation, and vulnerability WGII AR5 summary for policymakers. http://www.ipcc.ch/report/ar5/wg2/

lyengar NS, Sudarshan P (1982) A method of classifying regions from multivariate data. Econ Polit Weekly 17(51):2047-2052 Available at https://www.jstor.org/ stable/4371674

Kahsay B, (2013) Diagnosis and intervention plans for South Wollo Zone, Amhara Region: livestock and irrigation value chains for Ethiopian smallholders (LIVES). Amhara National Regional State, Ethiopia.

Kelly PM, Adger WN (2000) Theory and practice in assessing vulnerability to climate change and facilitation adaptation. Climatic Change 47(4):925-1352

Kothari CR (2004) Research methodology: Methods and techniques. New Age International. pp 152-183

Lawrence M, Lorreine C, Stephen B, Tanya B, Michele S, Julius H, ... Mekuria Z (2010) The Livelihoods Atlas of Ethiopia. The Livelihood Integration Unit: A Joint Government of Ethiopia and USAID Ethiopia Document.

Little PD, Stone MP, Mogues T, Castro AP, Negatu W (2006) 'Moving in place': drought and poverty dynamics in South Wollo, Ethiopia. J Dev Stud 42(2): 200-225. https://doi.org/10.1080/00220380500405287

Liu QQ, Chen L, Li JC (2001) Influences of slope gradient on soil erosion. Appl Math Mechanics 22(5):510-519. https://doi.org/10.1023/A:1016303213326

Liverman DM (1999) Geography and the global environment. Ann Assoc Am Geogr 89(1):107-120. https:/www.jstor.org/stable/2564037. Accessed 14Aug 2020

Mahoo H, Radeny M, Kinyangi J, Cramer L (2013) Climate change vulnerability and risk assessment of agriculture and food security in Ethiopia: which way forward? CCAFS Working Paper no. 59. CGIAR Research Program on Climate Change. Agriculture and Food Security (CCAFS), Copenhagen

Mekonnen Z, Woldeamanuel T, Kassa H (2019) Socio-ecological vulnerability to climate change/variability in central rift valley, Ethiopia. Adv Climate Change Res 10(1):9-20. https://doi.org/10.1016/j.accre.2019.03.002

MoANR/Ministry of Agriculture and Natural Resources (2016) Participatory Smallscale Irrigation Development Programme Phase II (PASIDP-II) Environmental and Social Management Framework (ESMF), Final Report. Federal Democratic Republic of Ethiopia, Addis Ababa 
MoEFCC/Ministry of Environment, Forest and Climate Change (2017) REDD+ MRV implementation in Ethiopia: Review of the context, framework and progress. Federal Democratic Republic of Ethiopia, Addis Ababa

Mohan D, Sinha S (2010) Vulnerability assessment of people, livelihoods and ecosystems in the Ganga Basin. WWF-India publisher, New Delhi. http://a ssets.wwfindia.org/downloads

Morand P, Kodio A, Andrew N, Sinaba F, Lemoalle J, Bene C (2012) Vulnerability and adaptation of African rural populations to hydro-climate change: experience from fishing communities in the Inner Niger Delta (Mali). Climatic Change 115(3-4):463-483

Moss RH, Brenkert AL, Malone EL (2001) Vulnerability to climate change: a quantitative approach. Richland: Technical Report PNNL-SA-33642, Pacific Northwest National Laboratories

MoWIE/Ministry of Water, Irrigation, and Electricity (2014) Preparation of watershed projects, Fincha'a'a catchment, Nile cooperation for results project. The Federal Democratic Republic of Ethiopia, Addis Ababa

Muller C, Cramer W, Hare WL, LotzeCampen H (2011) Climate change risks for African agriculture. Proc Natl Acad Sci USA 108(11):4313-4315. https://doi. org/10.1073/pnas.1015078108

Ndungu CK, Bhardwaj SK, Sharma DP, Sharma R, Gupta RK, Sharma B (2015) Vulnerability assessment of rural communities to environmental changes in mid-hills of Himachal Pradesh in India.

Negatu W (2004) Reasons for food insecurity of farm households in South Wollo, Ethiopia: explanations at grass roots. BASIS CRSP

Nelitz M, Boardley S, Smith R (2013) Tools for climate change vulnerability assessments for watersheds. Report prepared for the Canadian Council of Ministers of Environment (CCME).

Nyssen J, Frankl A, Zenebe A, Poesen J, Deckers J (2015) Environmental conservation for food production and sustainable livelihood in Tropical Africa. Land Degrad Dev 26(7):629-631. https://doi.org/10.1002/ldr.2379

O'Brien K, Leichenko R, Kelkar U, Venema H, Aandahl G, Tompkins H, Javed A Bhadwal S, Barg S, Nygaard L (2006) Mapping vulnerability to multiple stressors: Climate change and globalization in India. Glob Environ Change. 14:303-313

Patt A, Klein RJ, de la Vega-Leinert A (2009) Taking the uncertainty in climate change vulnerability assessment seriously. Comptes Rendus Geoscience 337: 411-424. https://doi.org/10.1016/j.crte.2004.11.006

Piya L, Maharjan KL, Joshi NP (2012) Vulnerability of rural households to climate change and extremes: analysis of Chepang households in the mid-hills of Nepal. Selected Paper Prepared for Presentation at "The International Association of Agricultural Economists (IAAE) Triennial Conference". Fozdo Iguacu, 18-24 August 2012

Rahmana M (2016) Land use and land cover changes and urban sprawl in Riyadh, Saudi Arabia: An analysis using multi-temporal Landsat data and Shannon's entropy index. International Archives of the Photogrammetry, Remote Sensing and Spatial Information Sciences 41(B8):1017-1021. https:// doi.org/10.5194/isprs-archives-XLI-B8-1017-2016

Samson J, Berteaux D, McGill BJ, Humphries MM (2011) Geographic disparities and moral hazards in the predicted impacts of climate change on human populations. Glob Ecol Biogeogr 20(4):532-544

Schneider S, Sarukhan J, Adejuwon J, Azar C, Baethgen W, Hope C et al (2001) Overview of impacts, adaptation, and vulnerability to climate change. Climate change 2001: impacts, adaptation, and vulnerability. Contribution of Working Group II to the Third Assessment Report of the Intergovernmental Panel on Climate Change. Cambridge University Press, Cambridge, United Kingdom and New York, NY, USA

Shawn W, Margles W, Vera NA, Lynnette M, Ben G, Steven RS, John EK, Ruth B (2016) Assessing vulnerability: an integrated approach for mapping adaptive capacity, sensitivity, and exposure. Climatic Change 136:615-629. https://doi. org/10.1007/s10584-016-1642-0

Sierra-Soler AJ, Adamowsk Z, Qi H Saadat, Pingale S (2015) High accuracy land use land cover (LULC) maps for detecting agricultural drought effects in Rainfed agro-ecosystems in Central Mexico. J Water Land Dev 26:19-35. https://doi.org/10.1515/jwld-2015-0014

Simane B, Zaitchik BF, Foltz JD (2014) Agro-ecosystem specific climate vulnerability analysis: application of the livelihood vulnerability index to a tropical highland region. Mitig Adapt Strateg Glob Change 21(1):39-65. https://doi.org/10.1007/s11027-014-9568-1

Smit B, Burton I, Klein RJ, Wandel J (2000) An anatomy of adaptation to climate change and variability. In: Societal adaptation to climate variability and change. Springer, Dordrecht, pp 223-251. https://doi.org/10.1007/978-94-017-3010-5_12
Smit B, Pilifosova O (2003) From adaptation to adaptive capacity and vulnerability reduction. In: Climate change, adaptive capacity and development, pp 9-28

Stroosnijder $L$ (2009) Modifying land management in order to improve efficiency of rainwater use in the African highlands. Soil Tillage Res 103(2):247-256

Sullivan C, Meigh J (2005) Targeting attention on local vulnerabilities using an integrated index approach: the example of the Climate Vulnerability Index. Water Sci Technol 51(5):69-78. https://doi.org/10.2166/wst.2005.0111

Sullivan CA, Byambaa E (2013) The application of the Climate Vulnerability Index in Mongolia. Paper presented to the workshop of climate adaptation. UNECE, Geneva

SWAD/South Wollo Agriculture Department (2018). South Wollo Agriculture Department 2016/17 Budget year Annual Report, Dessie. South Wollo Agriculture Office.

Teshome M (2016) Rural households' agricultural land vulnerability to climate change in Dembia woreda, Northwest Ethiopia. Environ Syst Res 5(14):1-18. https://doi.org/10.1186/s40068-016-0064-3

Tessema I, Simane B (2019) Vulnerability analysis of smallholder farmers to climate variability and change: an agroecological system-based approach in the Fincha'a sub-basin of the upper Blue Nile Basin of Ethiopia. Ecol Process 8:5. https://doi.org/10.1186/s13717-019-0159-7

Tesso G, Emana B, Ketema M (2011) Analysis of vulnerability and resilience to climate change induced shocks in North Shewa, Ethiopia. Agric Sci 3:871888. https://doi.org/10.4236/as.2012.36106.

Tesso G, Emana B, Ketema M, (2012). Analysis of vulnerability and resilience to climate change induced shocks in North Shewa, Ethiopia. Agricultural Sciences, 03(06), 871-888. https://doi.org/10.4236/as.2012.36106.

Turner BL, Matson PA, McCarthy JJ, Corell RW, Christensen L, Eckley N et al (2003) Illustrating the coupled human-environment system for vulnerability analysis: three case studies. Proc Natl Acad Sci 100(14):8080-8085. https://doi. org/10.1073/pnas.1231334100

UNDP/United Nations Development Programme (2016) A technical note: calculating the human development indices-graphical presentation.

USAID (2009) Ethiopia Livelihood Zones. http://www.fews.net/east-africa/ ethiopia/livelihood-zone Accessed 23 Nov 2017.

Walker J, Mitchell B, Wismer S (2001) Livelihood strategy approach to community-based planning and assessment: a case study of Molas, Indonesia. Impact Assess Project Appraisal 19(4):297-309. https://doi.org/1 $0.3152 / 147154601781766925$

Woodruff SK, Vitro T, BenDor, (2017). GIS and coastal vulnerability to climate change, 236-257. Chapel Hill: University of North Carolina at Chapel Hill. https://doi.org/10.1016/B978-0-12-409548-9.09655-X

World Bank (2004) Ethiopia: Country Economic Memorandum. A Regional Characterization Assessing Ethiopia's Growth Potential and Development Obstacles.

World Bank (2010) Economics of Adaptation to Climate Change: Ethiopia. Washington, DC. Retrieved from https://openknowledge.worldbank.org/ha ndle/10986/12504. Accessed 4 June 2020

Yohannes A (2012) Perceptions of climate change among members of the House of Peoples' Representatives, Ethiopia. J Risk Res 15:771-785. https://doi.org/1 0.1080/13669877.2012.657219

Yohe GW, Malone E, Brenkert A, Schlesinger M, Meij H, Xing X (2006) Global distributions of vulnerability to climate change. Integrated Assess 6(3):35-44

Youneszadeh S, Amiri N, Pilesjö P (2015) The effect of land use change on land surface temperature in the Netherlands. International Archives of the Photogrammetry, Remote Sensing and Spatial Information Sciences 41(W5):745-748

\section{Publisher's Note}

Springer Nature remains neutral with regard to jurisdictional claims in published maps and institutional affiliations. 